\title{
Práticas Diferenciadas de Governança Corporativa: Um Estudo sobre a Conduta e a Performance das Firmas Brasileiras*
}

\author{
Gabriel Srour ${ }^{* *}$
}

\begin{abstract}
Sumário: 1. Introdução; 2. Mecanismos de proteção aos minoritários: contratos privados e direito societário; 3 . Teoria e metodologia dos testes; 4. Banco de dados e seleção da amostra; 5. resultados; 6 . Conclusão.
\end{abstract}

Palavras-chave: governança corporativa; acionistas minoritários; convergência legal; convergência funcional; dividendos; contratos privados; ADR' s e crises.

Códigos JEL: G1; G3; K0.

Este artigo utiliza uma amostra de firmas brasileiras de capital aberto no período de 1997 a 2001 para investigar a eficácia de mecanismos alternativos de governança corporativa. Os dados demonstram que as firmas podem se comprometer com a proteção aos acionistas minoritários através do lançamento de ADR Nível II ou com a presença no Novo Mercado. Em particular, firmas com ADR Nível II ou do Novo Mercado possuem maiores retornos em períodos de crise e distribuem mais lucros sobre forma de dividendos. O estudo mostra, no entanto, que as mudanças no direito societário afetam a eficácia dos contratos privados. Assim sendo, as firmas não podem transpor completamente a fraqueza no sistema legal brasileiro que prejudica os acionistas minoritários.

This paper uses a sample of Brazilian firms in the period 1997 to 2001 to investigate the effectiveness of alternative corporate governance mechanisms. The data show that firms can commit to protect their minority shareholders by issuing Level II ADR's or joining the Novo Mercado. In particular, firms with Level II ADRs and firms in the Novo Mercado have larger stock returns in times of turmoil, and they are more likely to pay dividends. The study shows, however, that changes in corporate law affect the ability of private contracts like ADRs to protect minority shareholders. As such, firms cannot completely overcome weaknesses in the Brazil's legal system that harm minority shareholders.

* Artigo recebido em jul. 2004 e aprovado em abr. 2005. O autor agradece os comentários e sugestões de Walter Novaes, Heitor Almeida, Rogério Werneck e Marco A. Bonomo.

${ }^{* *}$ Gávea Investimentos. E-mail: gsrour@gaveainvest.com.br 


\section{Introdução}

A falta de transparência das firmas e sua conduta nem sempre correta com acionistas minoritários vêm sendo constantemente apontadas como origens para o mau funcionamento do mercado acionário, acarretando graves conseqüências para a eficiência da economia como um todo. Bons projetos deixam de ser financiados quando a firma não se compromete com a proteção dos interesses dos seus investidores.

Apesar da percepção de que uma melhor proteção aos acionistas minoritários facilitaria o desenvolvimento do mercado de capitais e o financiamento de novos projetos das empresas, países como o Brasil se viram em dificuldades, tanto políticas como institucionais, de promover mudanças na legislação que protegessem mais eficazmente os acionistas minoritários.

Em vista disso, a BOVESPA lançou a idéia da criação de um Novo Mercado, categoria onde só seriam listados papéis de empresas que aderissem a melhores regras de proteção aos acionistas minoritários e de maior transparência em suas contas. Inspirada na idéia do Neuer Markt alemão, esse projeto da BOVESPA teve como meta um melhor desenvolvimento do mercado de capitais brasileiro, dando, sobretudo, maior destaque aos esforços da firma na melhoria da sua relação com seus investidores. Esse processo seria representativo da idéia de "convergência funcional", exposta por Coffee (1999) e que se baseia na mudança de regras dentro dos próprios mercados sem a necessidade de alterações de caráter legal.

Na verdade, a idéia de convergência funcional não é consensual na literatura. Como Grossman e Hart (1986) apontaram, a dificuldade (ou até mesmo a impossibilidade) de se escrever contratos que determinem ações para cada estado da natureza requer um aparato legal que complete lacunas que são de grande relevância para o bom funcionamento do mercado de capitais. Caso a legislação seja falha para a proteção dos interesses dos acionistas minoritários, haveria redução na eficácia dos contratos privados. De acordo com este mesmo raciocínio, Johnson e Shleifer (2001) afirmam que não há clara evidência de que uma forte proteção ao investidor surja espontaneamente através de contratos privados ou de instituições políticas. O aumento da proteção dos investidores minoritários deveria estar, necessariamente, associado à instituição de sólidas regras internas de regulação e de transparência, que assegurariam melhor respaldo do poder judiciário na resolução de possíveis conflitos.

O objetivo deste artigo é analisar a eficácia dos mecanismos de contratos privados como provedores de proteção a investidores externos no Brasil. Johnson et alii (2000) demonstram, a partir de exemplos famosos de firmas da Itália, França e 
Bélgica, como é possível que a expropriação de benefícios privados pelo controlador seja feita dentro da lei local. Como mecanismos privados de atenuação de tais abusos, este artigo utilizará uma amostra de firmas brasileiras de capital aberto que emitiram ADR (American Depository Receipts) ou aderiram ao Novo Mercado no período entre 1997 e 2001.

Tal amostra é apropriada por várias razões. Em primeiro lugar, esse tipo de análise é particularmente interessante para um país como o Brasil, devido ao pouco rigor de sua legislação financeira e ao reduzido poder de cumprimento desta, ou seja, à existência de lacunas jurídicas. Em segundo lugar, como o plano de privatizações do governo promoveu modificações essenciais na legislação societária entre os anos de 1997 e 1999, a amostra abre oportunidades para se avaliar a relevância de possíveis alterações no conteúdo da lei, que seria, em última instância, responsável pela imposição normativa dos princípios básicos e gerais de proteção dos acionistas minoritários. Finalmente, durante esse período, diversas empresas brasileiras adotaram, voluntariamente, instrumentos mais rígidos de proteção aos acionistas minoritários.

A metodologia a ser seguida estará centrada na observação de características das firmas no que diz respeito a suas práticas de governança e a existência ou não de contratos privados para assegurar maior proteção aos acionistas minoritários. Para tanto, dois tipos de testes serão feitos. No primeiro, a amostra em estudo será dividida em dois grupos de acordo com a diluição dos recursos da firma imposta aos acionistas minoritários. Este teste relacionará diluição dos acionistas minoritários ao pagamento de dividendos, sendo assim coerente com a literatura em governança corporativa. ${ }^{1}$

As boas práticas de governança da firma determinam não apenas os incentivos dos controladores em diluir os minoritários mas também que ações os controladores tentarão implementar para restringir tais incentivos. Caso os contratos privados sejam realmente eficientes para a proteção dos interesses dos investidores externos, devemos encontrar relação entre a divisão proposta e o fato da firma estar (a) listada em bolsas americanas com regras mais rígidas de governança (através do lançamento de ADR' s que imponham práticas de boa governança); (b) presente no grupo de Nível 1 de Governança Corporativa da BOVESPA ou (c) submetida a uma auditoria de boa reputação que lhe garanta uma maior transparência de seus negócios.

\footnotetext{
${ }^{1}$ La Porta et alii (2000a).
} 
O principal resultado encontrado para esse primeiro teste é que os contratos privados podem ser importantes para a conduta da firma quando, de fato, impõem regras mais rígidas de governança corporativa e de transparência da firma. O lançamento de ADR Nível II afetou positivamente a probabilidade de uma firma pertencer ao grupo que dilui menos os acionistas minoritários, enquanto a presença de uma auditoria de boa reputação não pareceu ser determinante para melhores práticas de governança corporativa. A simples listagem de uma empresa brasileira no mercado americano através de ADR Nível I, cujo lançamento não faz maiores exigências para regras de governança e transparência, não foi associada à melhoria na sua conduta.

No segundo teste, foi explorada a eficácia desses mesmos contratos privados para as firmas brasileiras em situações extremas, tais como as vivenciadas durante a Crise Asiática, o choque da desvalorização do Real (janeiro de 1999) e, finalmente, durante a crise de 11 de Setembro. Seguindo a metodologia de Johnson et alii (2000), foi feita uma análise sobre o impacto de práticas mais rígidas de governança corporativa sobre a performance da firma em momentos de choques inesperados de retorno. Conforme o modelo destes autores, nos períodos caracterizados por choques de retorno, empresas com melhores práticas de governança teriam um retorno menos volátil em comparação com companhias que proporcionam menor proteção. Esse resultado decorre do objetivo do controlador da firma que, ao maximizar o seu benefício total, enfrenta o trade off em aumentar o valor da firma (dependente do retorno do mercado) ou em desviar recursos dos projetos. Por exemplo, em choques negativos de retorno, as boas práticas de governança mitigam o incentivo do controlador em desviar recursos, protegendo, assim, o valor da firma para os acionistas minoritários. Por outro lado, em momentos de choques positivos de retorno, o raciocínio inverso valeria e as firmas de pior governança teriam desempenho relativo melhor, uma vez que o incentivo à redução de desvios de recursos e sua conseqüente redução no valor de mercado das empresas é alterado de forma mais significativa para tais firmas. Dada a reconhecida falta de proteção oferecida pela legislação brasileira em ambientes de crises e incertezas, a amostra desse trabalho, mais uma vez, se mostra eficiente para um estudo com este foco.

Os resultados deste artigo mostram que as características das firmas relacionadas com suas governanças afetaram diretamente seus retornos observados durante os períodos de crises estudados. Em choques negativos, como o da Crise Asiática e da Crise de 11 de Setembro, empresas com melhores políticas de distribuição de dividendos ou com menor discrepância entre o poder de voto e propriedade do maior acionista experimentaram uma queda relativamente menor nos seus retornos. Enquanto isso, perante um choque positivo, como o da desvalorização do Real, essas 
mesmas boas características proporcionaram um menor retorno relativo para as firmas. Isto é, encontrou-se evidência robusta de que as boas características de governança diminuem a volatilidade do retorno em épocas de choque. A relevância dos contratos privados durante situações extremas também foi comprovada pelo fato de empresas participantes do grupo diferenciado da BOVESPA ou que estavam listadas nos programa ADR (de Níveis II e III) apresentaram, respectivamente, $6 \%$ e $7 \%$ de retorno relativo maior durante a Crise de 11 de Setembro.

Se a importância dos contratos privados foi constatada empiricamente neste artigo, o aspecto legal também teve respaldo dos dados. Nos dois tipos de testes, para o período de 1997 a 1999, no qual a legislação societária brasileira se encontrou fragilizada, constatou-se uma maior relevância da variável de discrepância entre o poder de voto e propriedade do maior acionista para a conduta e performance da firma. Este seria um indício de que os aspectos relacionados com o conflito de interesses entre o acionista controlador e os demais minoritários da firma dependeriam do rigor da legislação em vigor. Adicionalmente, esse resultado sugere que uma nova alteração da Lei das S.A. poderá trazer ganhos para os acionistas minoritários, complementando os benefícios advindos de mecanismos privados como ADR' s e regulamentações de bolsas de valores como a criação do Novo Mercado.

Este trabalho ratifica e complementa estudos recentes sobre governança corporativa e conduta da firma. Lins et alii (2004), por exemplo, estudaram como o lançamento de ADR' s pode afetar a sensibilidade do investimento das firmas em relação aos seus recursos internos. Os autores encontraram uma significativa redução dessa sensibilidade após o lançamento de ADR' s para as empresas oriundas de países de baixa proteção aos acionistas. Diante de um subseqüente aumento da participação de fontes externas para o financiamento dos projetos destas firmas, haveria evidência de melhoria nas suas práticas de governança. Um outro estudo, mais geral, sobre a integração de mercados e seus efeitos sobre o preço dos ativos foi feito por Miller (1999). O autor examinou o impacto da listagem de ações de firmas em mercados externos e encontrou retornos anormais positivos em torno da data de anúncio, o que suportaria a evidência de que há benefícios nesses processos. Companhias que lançaram ADR' s de Nível II ou III tiveram retornos anormais ainda maiores, sendo que as empresas que lançaram em Nível I praticamente não tiveram retornos anormais significativos.

Assim como este artigo, Mitton (2002) e Lemmon e Lins (2003) aplicaram o raciocínio de Johnson et alii (2000) para a crise asiática. Mitton estudou cerca de 400 firmas de cinco países do sudeste asiático que foram atingidos pela crise de 1997. Para analisar a característica de transparência e governância, Mitton utili- 
zou o fato das empresas possuírem ADR's (de qualquer nível) ou serem auditadas por uma grande companhia multinacional de alta credibilidade. Os resultados empíricos mostraram que empresas que possuíam ADR, de qualquer nível, obtiveram um retorno superior de $10,8 \%$ durante a crise e que aquelas auditadas por grandes companhias chegaram a um resultado superior de $8,1 \%$. Por outro lado, Lemmon e Lins examinaram 800 firmas de oito países asiáticos observando a variação do valor da firma durante a crise como função da sua estrutura de capital e do grau de proteção legal dado aos acionistas minoritários nesses diferentes países. Firmas nas quais existia uma maior concentração de propriedade tiveram um retorno relativamente inferior na ordem de $9 \%$ para o período da crise. Quando incluída uma variável indicativa ADR (de qualquer nível), Lemmons e Lins não encontraram efeito significante, ao contrário do reportado por Mitton. Mesmo quando a amostra foi reduzida para enquadrar os mesmos países utilizados por Mitton, Lemmons e Lins não constataram significância desta variável. Deve-se novamente ressaltar que, em ambos os estudos, todas as empresas que possuíam qualquer tipo de ADR foram utilizadas como sendo as de melhores práticas de governança, enquanto a literatura existente deste tópico constatou que apenas ADR' s de níveis superiores garantiriam melhor conduta da firma em relação aos seus investidores externos.

Diante desta inconsistência nos estudos anteriores sobre a importância do papel dos contratos privados relacionados às praticas mais rígidas de governança corporativa para a performance da firma, não seria possível transladar a sua relevância para as firmas brasileiras. Esse tipo de análise parece ainda mais interessante para um país como o Brasil, devido ao pouco rigor de suas leis financeiras e ao reduzido poder de cumprimento dessas regras, ou seja, à existência de lacunas jurídicas.

Por fim, a evidência empírica desse artigo também vai ao encontro do trabalho feito por Reese e Weisbach (2002), no qual os autores extraem o efeito governança das outras motivações da firma para a sua listagem em bolsas americanas, tais como o interesse em aumentar a liquidez da ação, em uma maior visibilidade da empresa ou em aproveitar vantagens tributárias. Reese e Weisbach testaram duas motivações para a listagem de uma firma estrangeira em bolsas americanas: desejo de ter acesso a novos mercados ou intenção de aumentar a proteção aos seus acionistas minoritários. Para tal, dividiram a amostra em duas regiões de acordo com o rigor adotado em relação às praticas de governança corporativa. Encontraram que as firmas de países onde a capacidade de expropriação do minoritário era alta tendiam a aumentar a freqüência de lançamento de novas ações domesticamente, enquanto que as firmas de países de maior proteção utilizavam o próprio mercado americano para tal. Isto comprovaria o interesse das firmas de países de menor 
proteção em utilizar o lançamento de ADR' s Níveis II e III para aumentar o seu padrão de governança, possibilitando novas captações no mercado doméstico, enquanto que as firmas das regiões de maior proteção estariam mais voltadas para a conquista de novos mercados.

Esse artigo contará com mais 5 seções. Na seção 2, será discutida a questão dos contratos privados (eficácia e mecanismos de cumprimento) e a importância legal. Na seção 3 serão apresentadas a teoria subjacente aos testes empíricos e suas respectivas metodologias. Na seção 4 serão descritos os períodos e as variáveis utilizadas nas regressões. A seção 5 apresenta os principais resultados e, por último, a seção 6 apresenta os comentários finais.

\section{Mecanismos de Proteção aos Minoritários: Contratos Privados e Direito Societário}

Na literatura recente de finanças corporativas tem havido esforços para a mensuração do efeito de práticas mais rígidas de governança corporativa nas mais diversas características da firma, bem como na decisão de financiamento de seus novos projetos e conseqüentemente no seu valor de mercado. Diversos artigos têm tratado dessa temática com um enfoque global, ou seja, comparando diversas estruturas legais de proteção aos acionistas minoritários e suas várias implicações em distintos países.

Em uma série de artigos, La Porta et alii pesquisaram o efeito de diferentes níveis legais de tratamento dado aos minoritários em diversos países. Concluíram que essas diferenças estariam relacionadas com a grande diversidade encontrada em relação ao grau de concentração de propriedade das firmas, ao desenvolvimento do mercado de capitais, à política de dividendos praticada e ao acesso da firma a novas fontes de financiamento externo. Concluíram que a abordagem legal é essencial para o bom entendimento das práticas de governança corporativa entre os países.

Origem dessas questões de governança corporativa, o conflito de interesses entre o controlador da firma e os demais acionistas minoritários decorre das várias formas nas quais o primeiro pode desviar recursos da empresa, ou seja, capturar benefícios privados da firma. As mais usuais são via transferência de recursos da firma em transações com outras empresas do interesse do controlador, a partir de contratos fraudulentos, compensação excessiva aos seus principais executivos, garantias de empréstimos da firma para negócios pessoais, expropriação de oportunidades de negócios e outras mais. Johnson et alii (2000) demonstram, a partir de exemplos famosos de firmas da Itália, França e Bélgica, como é possível que a expropriação 
de benefícios privados pelo controlador seja feita dentro da lei local. Diante destes fatos, fica evidente que o problema de governança corporativa não é exclusivo de países emergentes onde há pouca tradição de proteção aos acionistas minoritários.

Quando investidores externos de uma firma sabem que há grandes chances do retorno de suas aplicações não se materializarem integralmente devido a problemas de captura de benefícios privados por parte dos controladores, as regras de governança corporativa se tornam mecanismos fundamentais de proteção dos interesses dos acionistas minoritários. Como a expropriação pode se dar de diversos modos, a estrutura legal assume papel determinante para coibir as formas e magnitudes desta. Em circunstâncias onde os direitos dos investidores são extensivos e verificáveis em cortes legais, estes têm mais interesse em financiar a firma.

Dentre os principais direitos abordados para a boa proteção aos acionistas minoritários estão o de receber dividendos em datas pré-determinadas, de participar de assembléias e de novas subscrições, de ter o mesmo direito na venda da companhia do que seus controladores e outros mais. Segundo Coffee (1999), a percepção de que uma legislação mais forte promoveria claros benefícios à eficiência do mercado levaria a um processo de convergência do direito dos acionistas minoritários entre os países. Países de pouca tradição na proteção dos minoritários buscariam ajustes nas leis que favorecessem a participação destes nos negócios da firma e que impusessem, normativamente, práticas mais rígidas de governança corporativa. Denominado como "convergência legal", este processo estaria relacionado com mudanças na legislação e nos mecanismos de cumprimento destas novas regras, tais como reformas judiciais e de regulamentação.

Apesar desta constatação, países como o Brasil se viram em dificuldades, tanto políticas como institucionais, de promover mudanças na legislação que protegessem mais eficazmente os acionistas minoritários da firma. Desde a primeira versão da legislação societária brasileira, adotou-se um sistema de categorias de acionistas que, por não terem iguais direitos nem idênticas obrigações, passaram a ter interesses distintos.

De grande interesse para este trabalho, a legislação societária brasileira também já foi utilizada como instrumento institucional de política econômica em 1997, descaracterizando, assim, o seu papel de guardiã incondicional dos direitos dos investidores externos da firma. Em vista da implementação dos processos de privatização em setores estratégicos, a Lei 9.457 de 1997, conhecida como "Lei Kandir", suprimiu direitos fundamentais dos acionistas da firma. Foram extintos o direito de recesso ${ }^{2}$ dos acionistas minoritários nos casos de cisão, fusão e incorporação.

${ }^{2} \mathrm{O}$ direito de recesso pode ser entendido como a opção do acionista minoritário de se retirar da firma quando prejudicado por decisões da maioria dos acionistas em assuntos relevantes para 
Além disso, suprimiu-se a necessidade de oferta pública em caso de alienação de controle. Diante da visão de convergência legal, este enfraquecimento levaria ao aumento dos conflitos entre minoritários e controladores e a subseqüente diluição de valor da participação dos minoritários. Finalizado o período mais expressivo das privatizações, em 1999, a CVM estabeleceu a Instrução 299 cujo objetivo foi desfazer algumas das regras prejudiciais da Lei Kandir. Este artigo utilizará este período de alterações na legislação societária brasileira (tratado com um choque exógeno) para estudar o seu efeito sobre a política de distribuição dos lucros das firmas e sobre os seus retornos em períodos de crise.

Em decorrência dessas freqüentes alterações e diante da ausência de uma legislação ideal que regulasse a ação da firma em relação aos seus investidores externos, poderia ser interessante, então, que a própria firma procurasse formas próprias ou privadas de comprometimento.

Em vista disso, a BOVESPA lançou a idéia da criação de um Novo Mercado, categoria onde só seriam listados papéis de companhias que se comprometessem a ter melhores regras de proteção aos minoritários e de maior transparência em suas contas. O projeto está em andamento e algumas empresas já aderiram ao padrão de Nível 1 de Governança Corporativa, fase inicial para o ingresso ao Novo Mercado. Os seguintes critérios devem ser satisfeitos por uma empresa do Nível 1 de Governança Corporativa: manutenção em circulação de uma parcela mínima de ações (representando $25 \%$ do capital); realização de ofertas públicas de colocação de ações visando favorecer a dispersão do capital; melhoria nas informações prestadas trimestralmente, entre as quais a exigência de consolidação e de revisão especial e o cumprimento de regras de transparência em operações envolvendo ativos de emissão da companhia por parte de acionistas controladores ou administradores da empresa. Inspirada na idéia do Neuer Markt alemão, o projeto da BOVESPA tem como objetivo um maior desenvolvimento dos mercados de capitais no Brasil através do que Coffee (1999) também chamou de "convergência funcional", isto é, a promoção de mudanças nos contratos privados sem a necessidade de uma alteração mais ampla na legislação.

O Novo Mercado não é totalmente inovador nesse sentido. Coffee (1999) idealizou o processo de convergência funcional através da possibilidade de firmas sediadas em países de fraco aparato societário se listarem em bolsas de regiões com regras mais rígidas de governança. Em particular, firmas estrangeiras podem listar suas ações em bolsas americanas através das American Depositary Receipts (ADR's).

o funcionamento da firma. Nestes casos, o acionista minoritário receberia o valor patrimonial de suas ações. 
Atualmente, existem quatro tipos de ADR' s que variam segundo seus requisitos de transparência, regras de contabilidade, práticas de governança e mecanismos de colocação desses papéis, que podem ser feitos tanto no mercado de balcão quanto na própria bolsa em questão. O Nível I é o menos custoso para lançamentos públicos de ADR' s, podendo os negócios dessas ações ser feitos somente nos mercados de balcão das bolsas americanas. As companhias listadas nesse nível não precisam cumprir o US GAAP (Generally Accepted Accounting Principles) ou ter registro no S.E.C. (Securities and Exchange Comission), órgão de fiscalização do mercado americano. O custo fixo médio é relativamente baixo, sendo inferior a US\$25.000.

Já os recibos de Nível II são negociados nas bolsas NASDAQ, NYSE e AMEX e são utilizados por companhias que procuram maior liquidez e visibilidade, obrigando-as, no entanto, a terem regras mais rígidas de governança corporativa. As firmas devem adotar o US GAAP e se registrarem no S.E.C., além de cumprir a regulamentação da bolsa a qual estão listadas. Não é permitida nova oferta de capital, sendo negociadas apenas ações já existentes. O custo fixo médio varia de US $\$ 200.000$ a US $\$ 700.000$.

Como nível mais avançado, a listagem de ADR Nível III permite que a firma faça ofertas públicas de ações no próprio mercado americano, devendo também cumprir todos os requisitos do Nível II. O custo fixo pode alcançar US $\$ 2.000 .000$. Por fim, a empresa pode ainda optar por lançar RADR (Rule 144A Depositary Receipts) cuja colocação só pode ser feita privadamente. Esse tipo não exige que sejam atendidas as exigências do US GAAP nem da S.E.C. e o seu custo varia de US $\$ 250.000$ a 500.000 .

Em seu estudo, Coffee (1999) detalhou seis características das normas relativas à proteção do minoritário que são impostas às firmas estrangeiras listadas em bolsas americanas (e para certos níveis de ADR's) e que seriam úteis na melhoria da governança corporativa das firmas. Estas normas são apresentadas abaixo:

(i) A Seção 13(d) da S.E.C. Act requer que qualquer grupo que detenha mais de $5 \%$ do capital da empresa lhe reporte imediatamente. Essa regra pode ter um grande impacto sobre estratégias de troca de controle.

(ii) A Seção 14(d) da S.E.C. Act determina que, em qualquer oferta de fechamento de capital, deva-se garantir o mesmo preço para todos os acionistas minoritários, inclusive àqueles que possuem ações da empresa no mercado de origem.

(iii) As firmas estão sujeitas às regras das bolsas americanas. A NYSE, por exemplo, requer que a firma tenha pelo menos dois conselheiros externos no 
conselho de administração, auditores independentes e exigências de quorum qualificado para assembléias.

(iv) A Seção 13 (e) permite a S.E.C. regular o tratamento dado aos minoritários diante de negócios privados do controlador.

(v) Pelo Foreign Corrupt Practices Act, a firma deve manter todos os livros de contabilidade e registros de maneira transparente visando evitar corrupção.

(vi) A regra 10b-5 dá ao minoritário o direito de reembolso em transações fraudulentas feitas pelo controlador.

Além desse, outro mecanismo privado a ser testado neste artigo e que poderia garantir uma melhor transparência da firma e, conseqüentemente, a melhora dos mecanismos de governança, seria a contratação de companhias de auditoria independentes e de alta credibilidade. Devido a sua reputação, grandes auditorias possuem alto custo em ratificar balanços indevidos, podendo transmitir maior confiabilidade às informações prestadas pela empresa aos seus investidores externos.

A próxima seção mostra como se pode testar a eficácia destes mecanismos alternativos de proteção aos acionistas minoritários.

\section{Teoria e Metodologia dos Testes}

O objetivo dessa seção é formular testes para a eficácia da adesão de empresas brasileiras, via contratos privados, a condutas mais rígidas de governança. A subseção 3.1 trabalhará com a relação entre as variáveis de governança corporativa e a postura da firma em relação à diluição de seus acionistas minoritários, enquanto a subseção 3.2 terá sua atenção voltada para a performance da firma em momentos de extrema incerteza, onde a literatura em governança corporativa usualmente supõe que o papel dos contratos deve ser ainda mais importante.

\subsection{Diluição dos acionistas minoritários}

A hipótese a ser formulada nessa subseção está relacionada com a relevância dos contratos privados de boa governança para as decisões da firma que levem em conta a proteção dos interesses dos acionistas minoritários. Em um mundo sem problemas de governança corporativa, o investidor externo seria indiferente entre a distribuição dos lucros da firma em forma de dividendos ou a reinversão dos mesmos na companhia, já que esta última alternativa promoveria um aumento 
proporcional no valor da firma. No entanto, em firmas onde os interesses do controlador e dos investidores externos são conflitantes, o primeiro poderia desejar um maior acúmulo de recursos internos com a finalidade de aumentar o seu prêmio de controle (através da possibilidade futura de expropriação de benefícios privados). Em outras palavras, em firmas onde o problema de governança é mais grave, os lucros retidos e acumulados ao longo do tempo não seriam totalmente transferidos para os acionistas minoritários. Portanto, este artigo fará uso do pagamento de dividendos como uma medida de diluição dos acionistas minoritários da firma.

A utilização de dividendos como uma variável para de diluição dos acionistas minoritários vai ao encontro da evidência empírica do trabalho de La Porta et alii (2000a). Estes autores observaram que, em regiões marcadas por boa proteção aos acionistas minoritários e por práticas mais rígidas de governança corporativa, os investidores recebiam mais recursos da firma sob forma de dividendos.

A medida escolhida para ser indicativa dos níveis de diluição dos investidores externos foi o payout, ou seja, a proporção dos lucros da firma que é proposta para ser redistribuída aos acionistas da firma em forma de dividendos. Ela é calculada no final de cada ano observando-se o quanto cada empresa destina dos seus lucros do exercício para o pagamento futuro de dividendos, sendo, assim, uma medida da intenção da firma em redistribuir recursos aos acionistas minoritários. A escolha dessa medida explora a mesma linha do trabalho de La Porta et alii (2000a). ${ }^{3}$ Vale a pena ressaltar que, apesar da percepção de que as firmas brasileiras pagariam pouco dividendos em virtude de problemas de restrição de crédito, encontrou-se na amostra uma grande diversidade nos payouts das firmas, o que a garantiu a sua utilização neste estudo.

Pode existir, no entanto, um viés na medida de payout. Como a extração de benefícios privados deve ocorrer antes da apuração dos lucros das firmas, empresas de pior governança teriam seu payout superestimado. Isso tenderia a viesar os resultados fazendo com que empresas de pior governança tivessem um payout maior, uma vez que parte do lucro existente já teria sido desviada. No entanto, se constatarmos o resultado oposto, estaremos encontrando evidência ainda mais forte sobre a relação entre governança corporativa e diluição dos acionistas minoritários.

\footnotetext{
${ }^{3}$ Por contarem com uma amostra composta por firmas de diversos países (e com distintas normas contábeis), os autores calcularam três medidas de payout. Todas têm no numerador o pagamento de dividendos, sendo que no denominador foram utilizados o lucro da firma, a receita e o valor das suas vendas.
} 
Escolhida essa variável, para cada período analisado, dividiu-se a amostra de 350 companhias abertas em dois grupos: grupo que dilui mais os seus investidores externos (Grupo I) e grupo que dilui menos seus investidores externos (Grupo II). Três períodos foram selecionados para essa análise: de 1997 a 2000, de 1998 a 2000 e de 1999 a 2000. Com a inclusão desta dimensão temporal, pretendeu-se verificar as possíveis mudanças ao longo do tempo no comportamento da firma em função das suas variáveis de governança corporativa e dos distintos ambientes de proteção aos direitos dos minoritários. A divisão dos grupos, em cada período, foi feita adotando-se a seguinte metodologia: ordenaram-se todas as firmas que tiveram lucro no período de acordo com o seu payout e calculou-se a média cross-section dessa variável, retirando-se, no entanto, as firmas que possuíam payout nos dois primeiros e dois últimos percentis. ${ }^{4}$ As firmas que tinham payout inferior a essa média foram enquadradas no Grupo I (de maior diluição) enquanto as restantes foram enquadradas no Grupo II. Para as firmas que possuíam payout negativo, ou seja, tiveram prejuízo no período e mesmo assim redistribuíram recursos, fezse o mesmo procedimento, alocando-as nos mesmos dois grupos de acordo com a relação de seu payout com o payout médio de uma empresa que teve prejuízo.

Diante disso, estimou-se a probabilidade de uma firma fazer parte do grupo II, de menor diluição, condicional às variáveis indicadoras de maior proteção aos interesses dos acionistas minoritários. ${ }^{5}$ Tais variáveis, bem como as demais variáveis de controle, são medidas imediatamente antes do sub-período analisado. Para essa medida utilizou-se a listagem das firmas nos programas ADR Nível I (sem exigências de governança corporativa), ADR Nível II (com exigências de governança corporativa) e sua presença no índice Nível 1 de Governança Corporativa da BOVESPA (criado em Agosto de 2001 como pré-requisito do Novo Mercado). ${ }^{6}$ Para a medir o impacto das auditorias de boa reputação utilizou-se uma variável indicadora da presença de auditorias do grupo das big five. ${ }^{7}$

A inclusão da variável indicadora do Nível 1 de Governança Corporativa da BOVESPA não teria sentido se o único intuito fosse analisar o impacto desse contrato sobre a determinação do nível de diluição da firma, uma vez que este só

\footnotetext{
${ }^{4} \mathrm{O}$ objetivo foi evitar que observações muito discrepantes influenciassem o cálculo da média da variável.

${ }^{5}$ Foi utilizado um modelo Probit que considera que a função de densidade dos regressores (características da firma que afetam a sua decisão em diluir seus acionistas minoritários) é normal.

${ }^{6}$ Como não havia na amostra empresas com ADR Nível III, não se incluiu esta variável.

${ }^{7} \mathrm{O}$ grupo das big five é formado por: Arthur Andersen, Ernst \&Young, Price WaterHouse Coopers, Deloitte Touche Tohmatsu e KPMG. Após os escândalos corporativos de 2002 nos Estados Unidos e o envolvimento da consultoria Arthur Andersen o grupo se restringiu aos outros quatro membros, sendo denominado big four.
} 
passou a existir a partir de 2001. No entanto, ao incluir essa variável, podemos estudar se a escolha da firma em fazer parte desse grupo diferenciado estaria ligada às suas próprias e já existentes características de governança que também estariam afetando a sua conduta em relação aos acionistas minoritários.

Existem, porém, outras variáveis que representam medidas de governança corporativa mas que não estão diretamente relacionadas com a assinatura de contratos privados. Por exemplo, o desejo do acionista controlador em expropriar recursos da firma é limitado pelos seus incentivos financeiros para tal. Esse é o resultado clássico do modelo de Jensen e Meckling (1976) que explica um dos aspectos mais relevantes sobre a concentração de propriedade e sua relação com governança corporativa. Diante disso, empresas onde há uma grande discrepância entre o poder de voto do controlador e seu direito de propriedade estariam mais vulneráveis a conflitos de interesses entre seus sócios. Para testar essa implicação, uma variável que mede tal discrepância também terá lugar na regressão. Cabe ressaltar que este conflito de interesses será ainda mais relevante em um ambiente jurídico favorável à expropriação do minoritário e à retenção dos recursos da firma visando o aumento do prêmio de controle desta.

Pode-se testar também essa última afirmação durante o período analisado, uma vez que houve modificações essenciais na Lei das S.A. e na regulamentação da CVM, ambas com conseqüências relevantes para o conflito de interesses entre o controlador e os acionistas minoritários da firma. Como já se mencionou acima, em virtude do processo de privatização, fortemente potencializado nos anos de 1997 a 1999, o Congresso Nacional aprovou a Lei 9.457/97 que alterou aspectos relevantes da Lei das S.A. de 1976. A expropriação dos acionistas minoritários foi facilitada na medida em que houve um enfraquecimento do direito de recesso e suprimiu-se a extensão de oferta de compra a todos os acionistas nas ocasiões de negociação do controle da firma. Além disso, também foi extinto o direito existente do acionista ordinário em ter o mesmo preço na venda ou transferência de um bloco de controle da empresa. Nestas operações também não se tornou mais necessária a divulgação pública dos termos e das condições envolvidas no processo.

Passada a etapa mais expressiva das privatizações em 1999, a CVM estabeleceu a Instrução 299 tentando remediar a piora promovida anteriormente no direito dos acionistas minoritários. Qualquer acionista detentor de mais de $10 \%$ de propriedade da empresa passou a ter o direito de participação no processo de venda de bloco superior a $5 \%$ do controle da firma. Além disso, foram criadas regras mais rígidas para o direito de recesso e condições menos prejudiciais aos acionistas minoritários nas operações de fechamento de capital. 
A hipótese básica a ser testada, portanto, é que as firmas que lançaram ADR Nível II, que se listaram no Novo Mercado ou que possuíam auditorias de boa reputação promoveram uma menor diluição dos acionistas minoritários. Nesta estimação, também serão incluídas dummies setoriais ${ }^{8}$ diante do fato estilizado sobre as similaridades de distribuição dos lucros das firmas entre os diferentes setores da economia. Além disso, a liquidez da ação em bolsa, o seu nível de alavancagem, o tamanho da firma e o valor relativo do lucro em relação ao ativo da firma também foram incluídos como variáveis explicativas. Em relação a esta última variável, espera-se que seja mais fácil que empresas redistribuam um percentual maior dos seus lucros quando estes são relativamente mais fartos, ou seja, quando o que restar para a empresa também seja relativamente mais significante para suas novas decisões. Note que essa medida também pode ser vista como indicadora da lucratividade da empresa, sendo esta utilizada por La Porta et alii (2000a).

\subsection{Performance das firmas em choques de retorno}

Além do efeito de contratos para práticas diferenciadas de governança corporativa sobre a conduta da firma em relação à distribuição de dividendos, também seria interessante testar a sua relevância para a performance da firma em momentos de grande incerteza, como os caracterizados por choques de retorno.

Usando como conjectura os acontecimentos decorrentes da Crise Asiática, Rajan e Zingales (1998) argumentam que os investidores ignoraram as práticas de governança corporativa das firmas asiáticas enquanto os negócios iam bem. No entanto, durante o período de crise, imediatamente desfizeram suas posições em países onde havia pouco comprometimento legal entre os acionistas e o controlador, afetando assim a performance destas firmas. Essa conjectura encontrou suporte empírico no trabalho realizado por Johnson et alii (2000), no qual formalizou-se tal implicação a partir de uma modelagem teórica.

A hipótese a ser formulada nessa subseção pode ser vista, assim como as dos trabalhos de Mitton (2002) e Lemmon e Lins (2003), como decorrente do modelo de Johnson et alii (2000). Caso as variáveis de governança corporativa afetem o retorno de empresas em épocas de crises inesperadas de retorno, os contratos privados para boas práticas de governança devem ser ainda mais relevantes nestes momentos de extrema incerteza.

Como hipótese alternativa para este tipo de teste, precisa-se de algum outro modelo que explique o retorno de ações em um determinado período. Para conduzir esta abordagem será necessário que tenhamos um modelo padrão de previsão

\footnotetext{
${ }^{8}$ Foram incluídas 18 dummies setoriais utilizando o critério da Economática.
} 
de retornos. Para tanto usaremos o modelo do CAPM. A escolha deste modelo foi feita em detrimento, por exemplo, do modelo de 3 fatores de Fama e French (1996) que além do retorno de mercado leva em consideração o retorno de outros dois portfolios específicos. ${ }^{9}$ Freqüentemente utilizado para dados americanos em análises seccionais e com alguma dimensão temporal, o modelo de 3 fatores poderia ser implementado nesse trabalho, não fossem problemas relacionados à amostra envolvida. Uma vez estimado esse modelo para a amostra em questão, de 1994 até 2000, os coeficientes estimados destes dois portfolios adicionais foram insignificantes na maior parte das vezes. Para uma amostra de cerca de 30 empresas, o modelo padrão do CAPM calculado com 60 dados mensais forneceu todas as 30 estimações do beta (coeficiente em relação ao portfolio de mercado) significantes. Por outro lado, o modelo de 3 fatores forneceu para os outros dois coeficientes (associados aos portfolios de Fama e French) apenas 11 coeficientes significantes num total de 60 estimados. Sendo esses coeficientes estimados como insignificantes, por razões econométricas óbvias, não poderiam ser utilizados como variáveis explicativas da regressão proposta nessa subseção.

Apesar disso, algumas variáveis fundamentalistas, que estariam relacionadas com as idéias de Fama e French a respeito da importância dos outros portfolios específicos na previsão de retornos de empresas cross-section, serão utilizadas. Um estudo feito com dados brasileiros por Costa Jr (2000) constata que embora certas variáveis fundamentalistas tenham alguma influência nas explicações das variações nas rentabilidades das ações brasileiras, o Beta do CAPM continua sendo fortemente representativo para a previsão de retornos. Apesar disto, os autores encontraram que o índice de preço sobre lucro da firma, o valor de mercado desta e o índice de valor patrimonial da ação em relação ao seu preço são significativos para a explicação do retorno de empresas brasileiras em regressões seccionais. Costa e Neves argumentam que estes índices são proxies para a construção dos portfolios imaginários de Fama e French. Estas variáveis fundamentalistas, abordadas em tal estudo, foram, então, incluídas como controles para a explicação dos retornos das ações brasileiras na regressão proposta nesta subseção.

Diante disto, para um determinado período de crise, testou-se o seguinte modelo:

\footnotetext{
${ }^{9}$ Esses dois portfolios são conhecidos como SMB e HML. O primeiro portfolio é composto analisando o valor de mercado de todas as empresas. Compõe-se por uma posição comprada em firmas que estão no decil inferior e por uma posição vendida em firmas que estão no decil neste quesito. O segundo portfolio é composto analisando razão do valor contábil da empresa em relação ao seu valor de mercado. Compõe-se por uma posição vendida em firmas que estão no decil inferior e por uma posição comprada em firmas que estão no decil superior neste quesito.
} 
Retorno no período da crise $=\alpha+\beta_{1} * A D R$

$+\beta 2 *$ ADR Níveis II e III

$+\beta 3 *$ Discrepância entre direito de voto e propriedade $+\beta 4 *$ Payout

$+\beta 5 *$ Beta do CAPM $+\beta 6 *$ Alavancagem $+\beta 7 *$ Tamanho da Firma

$+\beta 8 *$ Liquidez em Bolsa $+\gamma *$ Variáveis Fundamentalistas $+\epsilon$

A variável $A D R$ é uma indicadora que assume valor 1 se a empresa estiver listada no mercado americano antes do período da crise em questão e 0 em caso contrário. A inclusão dessa variável tem a função de controlar o efeito marginal das ADR' s que não esteja exclusivamente ligado ao seu efeito de governança. A variável ADR Níveis II e III é uma indicadora que assume valor 1 caso a firma possua ADR Nível II ou Nível III e 0 em caso contrário. Essa última dummie seria a responsável pelo papel dos contratos privados de melhores práticas de governança corporativa. Caso estes sejam importantes em momentos de crise, deveríamos constatar, segundo o raciocínio do modelo de Johnson et alii (2000), um efeito significante dessa variável na determinação do retorno relativo das empresas.

A partir da inclusão dessas duas variáveis de ADR, espera-se encontrar dois efeitos da listagem de empresas brasileiras em bolsas americanas. O primeiro e mais relevante para esse trabalho seria o da imposição de padrões mais rígidos de governança corporativa através de contratos privados. Este é dado pela variável ADR Níveis II e III. O segundo efeito, capturado pela variável ADR, seria decorrente da maior exposição que as empresas listadas em bolsas americanas têm aos investidores internacionais. Por uma série de facilidades, que vão desde a redução de custos de corretagem até a possibilidade de se evitar qualquer tipo de entrave existente para a movimentação do capital estrangeiro, estes papéis são mais acessíveis ao investidor estrangeiro. Em vista disso, em momentos de crises internacionais ligadas a países emergentes e diante de seus efeitos de contágio, os investidores externos podem se desfazer mais rapidamente dessas ações, que lhes são mais líquidas e permitem maior facilidade de negociação. Logo, em épocas de crise, os papéis de companhias brasileiras que possuem ADR sofreriam um grande movimento de venda por parte dos investidores externos contagiados por perdas em outros países emergentes, tendo sua cotação afetada negativamente. Note que este efeito aumenta a volatilidade do retorno da firma em relação ao retorno do mercado, ou seja, é contrário ao primeiro efeito de governança discutido.

As outras variáveis de governança como o payout (diluição dos acionistas minoritários) e a discrepância entre o poder de voto e de propriedade devem, ainda 
segundo as implicações do modelo de Johnson et alii (2000), ter impacto sobre os retornos das empresas em épocas de crise. Firmas com piores características de governança (menor payout ou maior discrepância entre poder de voto e propriedade) deveriam ter performances relativas inferior em períodos de choques negativos de retorno. A respeito da confiabilidade dos balanços das empresas, não se adicionou a variável indicativa big five, já que todas as empresas com ADR' s que fizeram parte da amostra de crises também eram auditadas por companhias ditas de boa reputação. Todas as variáveis independentes (do lado direito da equação) foram medidas no período anterior a cada crise, visando diminuir possíveis problemas de endogeneidade nas variáveis.

Os demais regressores, tais como Alavancagem, Tamanho da Firma e Liquidez em Bolsa foram utilizadas como controles adicionais da regressão. Devido ao fato estilizado de que empresas com maior alavancagem, medida como o valor da dívida sobre o valor do capital da firma, têm desempenho pior em épocas de crise, essa variável teve espaço na regressão proposta. Para evitar que uma maior liquidez dos papéis advinda do lançamento de ADR' s fosse vista como causa de uma possível redução do efeito da volatilidade do mercado sobre o retorno dessas empresas, adicionou-se como controle na regressão uma variável que mede liquidez da ação em bolsa.

\section{Banco de Dados e Seleção da Amostra}

Foram coletados dados de balanços trimestrais e de retornos diários de 350 empresas brasileiras de capital aberto para o período compreendido de Janeiro de 1997 a Dezembro de 2001. As fontes primárias de dados foram os bancos de dados da Economática e da CVM (Comissão de Valores Mobiliários). Além de se tratar de um período onde diversas empresas lançaram ADR, a escolha deste período também teve como objetivo capturar as alterações ocorridas na legislação societária brasileira entre os anos de 1997 e 1999, oferecendo, assim, oportunidades para se avaliar a relevância de possíveis alterações no próprio conteúdo da lei.

Para a construção da variável de discrepância do poder de voto e propriedade, calculou-se a proporção de ações ordinárias (com direito a voto) que o maior acionista da firma possuía em relação à proporção de suas ações totais (ordinárias mais preferenciais). Como só se observou a forma de controle direta sobre a firma, pode se estar cometendo um erro, uma vez que Valadares e Leal (2000) constatam que as concentrações de propriedade diretas e indiretas são muito diferentes para o Brasil. ${ }^{10}$ No entanto, se utilizarmos os dados de concentração de propriedade

\footnotetext{
${ }^{10}$ Enquanto os controladores diretos são os acionistas que possuem ações da empresa em
} 
do ano de 1997 deste mesmo estudo, a variável aqui introduzida de discrepância entre o poder de voto e de propriedade do maior acionista é praticamente a mesma, calculando-se tanto pelo método de detenção direto ou indireto de ações ordinárias e preferenciais. ${ }^{11}$

Objetivando o conhecimento das companhias que auditam as empresas abertas brasileiras, consultou-se o Cadastro Geral da CVM. Construiu-se uma variável que indica se a empresa é auditadas por uma companhia das big five ou não. Das 350 empresas de capital aberto, 259 eram auditadas por companhias de grande reputação no período de 1997 a 2000. A constatação destes dados nos permite dizer que, caso as auditorias de boa reputação fossem utilizadas para algum tipo de sinalização, estaríamos em algum equilíbrio do tipo pooling. Pela quantidade relativa de empresas com auditorias de big five e a sua diversidade entre práticas de proteção aos acionistas minoritários, não podemos dizer que o investidor possa utilizar esse fato para distinguir empresas com balanços confiáveis. Quando se observa os inquéritos administrativos abertos pela CVM para investigar falhas nos balanços de empresas, não há como dizer que, de fato, as auditorias de boa reputação sejam aquelas nas quais o investidor possa confiar mais.

O banco de dados das empresas brasileiras que já lançaram ADR e seus mais diferentes níveis foi construído através da informação prestada pelo Bank of New York. Desde 1994, 47 empresas já lançaram algum tipo de ADR e foram listadas nas mais diversas bolsas americanas, tais como a OTC, NASDAQ e NYSE. A grande parte dessas empresas (45 de 47) são auditadas por alguma companhia das big five. A companhia Suzano de Papel e Celulose foi a primeira empresa brasileira a lançar ADR, sendo que em outubro de 1993 já fazia parte da OTC com ADR de Nível I. Até dezembro de 2001, 19 dessas 47 companhias já haviam adquirido o Nível II e apenas 6 conquistaram o nível mais elevado, ou seja, tinham ADR Nível III. Apesar do número relativamente grande de empresas com ADR de níveis diferenciados de governança corporativa em dezembro de 2001, até janeiro de 1998 apenas 4 empresas possuíam outros níveis de ADR que não o de Nível

questão, os indiretos são detentores de outras empresas que possuem participação dessa firma. Logo, em última instância, também são proprietários da firma em questão podendo exercer controle indireto sobre a mesma.

${ }^{11}$ Das 325 companhias estudas por Valadares e Leal no ano de 1997, o acionista majoritário detinha, em média, $74 \%$ das ações ordinárias da empresa, mas com apenas $51 \%$ do capital total. Isto resulta em uma medida de discrepância direta entre poder de voto e propriedade de 1,45. Quando o alvo de estudo foi à concentração indireta de propriedade, os autores constataram que esta é menos acentuada. Nas empresas onde existia um controle indireto, via a posse de mais da metade de seu capital votante, o controlador detinha em média $51 \%$ dessas ações e possuía apenas $35 \%$ do capital total da empresa. Isto também nos fornece uma discrepância entre poder de voto e propriedade de 1,45. 
I. A presença de poucas observações de empresas com ADR Nível II em duas das três crises estudadas acabou por comprometer a significância das estimações e dificultar o exame desta variável específica na determinação da conduta das firmas no período anterior a 2001.

A tabela 1 traz as principais estatísticas das variáveis utilizadas na estimação da probabilidade das firmas participarem dos grupos de maior ou menor diluição dos acionistas minoritários. Nas duas primeiras colunas podem ser vistas as médias das variáveis em cada grupo, enquanto a terceira coluna apresenta a probabilidade (p-valor) destas médias atingirem tais valores caso fossem, de fato, idênticas. Por esta tabela, percebe-se que não há diferença significante a $5 \%$ na média de empresas com ADR Nível I entre os grupos em qualquer período analisado. O mesmo ocorre para a presença de auditorias de boa reputação e para listagem no Nível 1 de Governança Corporativa da BOVESPA. Já o lançamento de ADR' s Nível II foi feito mais freqüentemente por companhias que diluem menos os seus acionistas minoritários, principalmente para o período mais recente da amostra.

Uma vez que o exercício econométrico formulado na seção 3.2 propunha o tratamento com retornos de firmas em bolsa, precisou-se selecionar dentro da amostra de 350 empresas aquelas que possuíam liquidez e volume em bolsa suficientemente representativos. Para tanto, assim como Johnson et alii (2000), utilizou-se o critério do International Finance Corporation (IFC) a fim de destacar as empresas mais relevantes em bolsas e na economia de um determinado país. Segundo esse critério, teríamos 56 empresas brasileiras, mas muitas delas não tinham liquidez em bolsa suficiente para utilizarmos o seu preço como bom indicador econômico de sua performance. Para o estudo de crises, calculou-se a liquidez em bolsa ${ }^{12}$ de todas as empresas no trimestre imediatamente anterior a crise fazendo-se a interseção entre as 70 firmas mais líquidas da BOVESPA no período anterior a crise e aquelas pertencentes ao índice do IFC. Desta interseção, foi criada a amostra de empresas para cada crise estudada. As principais estatísticas descritivas das variáveis das empresas que fazem parte das amostras de cada crise encontram-se na tabela 2 .

\footnotetext{
${ }^{12}$ Utilizou-se uma medida de liquidez em bolsa fornecida pela Economática que leva em consideração o número de dias no período em questão onde se teve pelo menos um negócio com a ação da firma, o número de negócios e o volume em dinheiro com os papéis da firma no período e o número de negócios e o volume em dinheiro com todos os papéis da bolsa no período.
} 
Conforme mencionada na subseção 3.2, a abordagem econométrica que se seguirá para a mensuração do impacto de práticas diferenciadas de governança sobre os retornos das empresas deverá ser feita para períodos de choques inesperados de retornos. Diante disso, como um dos aspectos de maior importância, surge a necessidade de se obter uma metodologia para seleção dos períodos de crise. Nos artigos de Mitton (2002) e de Lemmon e Lins (2003), a única crise analisada foi a asiática e esta foi periodizada pelos autores de julho de 1997 a agosto de 1998. A metodologia adotada por estes dois artigos foi baseada na observação da evolução dos índices das bolsas dos países asiáticos próxima aos dias em que se deflagraram notícias freqüentemente associadas com o início e o fim da crise asiática. O momento em que houve uma queda abrupta do mercado acionário foi estipulado como o de início da crise e quando o índice do mercado voltou a ser estabilizar em outro patamar, configurou-se o fim da crise.

Essa mesma metodologia foi utilizada neste artigo, mas a determinação exata das datas de início e de fim das crises nesse processo é, sem dúvidas, subjetiva, uma vez que notícias e fatos que caracterizam qualquer crise se sucedem por vários dias. Para testar a robustez da escolha dessas datas, estimou-se a mesma regressão para datas próximas daquelas escolhidas como as de início e término de cada crise, ampliando-se ou reduzindo-se a janela observada. Estes resultados não são reportados por este trabalho, mas apesar das magnitudes dos coeficientes estimados serem sensíveis à janela escolhida, os seus sinais e os níveis de significância mostraram-se robustos a tais modificações.

Mais do que uma boa delimitação do período de crise, é de fundamental importância para a coerência do modelo que esta seja inesperada. Para tanto, destacaram-se 3 choques internacionais de grandes proporções para a mudança da lucratividade esperada do mercado internacional e brasileiro. Estas estão indicadas na figura 1 e são conhecidas por: Crise Asiática (julho de 1997 a agosto de 1998), Desvalorização do Real (janeiro de 1999 a janeiro de 2000) e Crise de 11 de Setembro (setembro de 2001). 
Figura 1

A evolução do Índice IBOVESPA e os períodos de choque de retorno

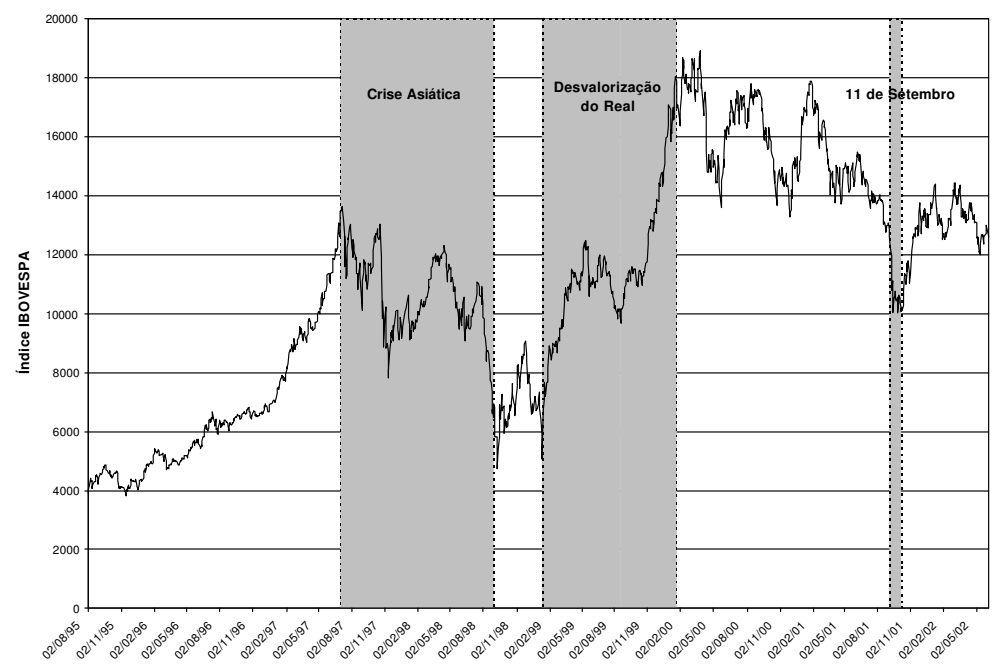

\section{Resultados}

\subsection{Diluição dos acionistas minoritários}

Conforme mencionado na subseção 3.1, três períodos foram selecionados para a conduta da firma em relação à diluição de seus acionistas minoritários: de 1997 a 2000, de 1998 a 2000 e de 1999 a 2000. Os resultados das estimações de um modelo Probit para a probabilidade de uma firma pertencer ao grupo de menor diluição dos seus acionistas minoritários nesses períodos se encontram na tabela 3. Com a inclusão desta dimensão temporal, pretendeu-se verificar as possíveis mudanças ao longo do tempo no comportamento da firma em função das suas variáveis de governança corporativa. Devido aos problemas de falta de observação para todas as variáveis, a amostra foi reduzida de acordo com a disponibilidade destas informações, tendo-se, em média, um número de 171 empresas em cada estimação. $^{13}$

\footnotetext{
${ }^{13}$ No período de 1997 a 2000, de 1998 a 2000 e de 1999 a 2000 foram utilizadas respectivamente 195, 176 e 142 firmas. 
Como podemos observar na tabela 3, para os períodos mais recentes, a listagem da firma no Nível 1 de Governança Corporativa da BOVESPA afetou significativamente a probabilidade da firma pertencer ao grupo de menor diluição (Grupo II). O fato deste coeficiente estimado ser significante apenas para o período mais recente demonstra que a listagem diferenciada da BOVESPA estaria captando características mais favoráveis às boas práticas de governança corporativa justamente no período mais próximo à assinatura deste contrato. Como no período em que foi feita esta análise tal contrato ainda não existia, não podemos afirmar se este foi determinante para o comportamento da firma em diluir mais ou menos seus acionistas minoritários. No entanto, foram encontradas evidências de que as empresas que optaram pela inclusão na bolsa diferenciada da BOVESPA já possuíam melhores características relacionadas a sua conduta para distribuição de recursos entre seus acionistas minoritários.

Em relação à listagem em bolsas americanas e ao nível de comprometimento firmado, a evidência empírica também confirmou a relevância deste tipo de contrato. Os coeficientes estimados para as empresas que possuíam ADR Nível II foram todos significantes (a 1\% de confiança) nos períodos mais recentes (de 1999 a 2000 e de 1998 a 2000). Conforme descrita na subseção 2.1, a listagem de ADR Nível II conta com requisitos de governança corporativa não existentes no lançamento de Nível I, tais como a adoção do US GAAP, a imposição da regulação da S.E.C e de outras regras de transparência e governança impostas pelas próprias bolsas americanas. Isso ratifica, em termos de dados brasileiros, a evidência da literatura descrita na seção 1. De acordo com os estudos de Miller (1999) e Reese e Weisbach (2002) os ganhos na listagem de ADR em termos de governança corporativa são dependentes do nível de ADR utilizado, sendo esses inexistentes para ADR Nível I e significativos para o Nível II.

Segundo revela a tabela 1 descrita na seção 4, basicamente não existe diferença significante na média de empresas com ADR que fazem parte dos Grupos I e II e controlando-se por todas as outras variáveis o efeito pareceu ser insignificante. A probabilidade (p-valor) das médias serem iguais é significante a $5 \%$ para todos os períodos. Pela própria construção dessas variáveis dummies, a variável indicadora ADR englobou todas as empresas que já haviam lançado ADR enquanto que a dummie ADR Nível II apenas diferenciou as firmas com esse tipo de contrato. Assim, o sinal insignificante da variável ADR indica que o lançamento de ADR apenas no Nível I pareceu não afetar de modo significante a participação de empresas no grupo de maior proteção aos acionistas minoritários. ${ }^{14}$ Pôde-se, então, concluir que um contrato privado com regras claras de governança e transparência

\footnotetext{
${ }^{14}$ Ressalta-se, novamente, que não existem empresas com ADR's Nível III para essa amostra.
} 
afetou significativamente a conduta da firma em relação aos seus acionistas minoritários, enquanto a simples presença da empresa no mercado americano sem a imposição de regras mais rígidas não pareceu ser eficaz neste sentido.

Em relação à presença de uma auditoria de boa reputação, esta não demonstrou poder impactar a probabilidade da firma participar do grupo de melhor proteção aos acionistas minoritários. Pela tabela 3, constata-se que durante o período de 1999 a 2000 a presença das auditorias de boa reputação acabou até por aumentar a probabilidade da firma fazer parte do Grupo I, ou seja, foi indicativo de uma pior conduta em relação aos minoritários. A falta de relação ou até mesmo o efeito inverso entre a conduta da firma e a escolha de auditorias de boa reputação pode ser um indicativo que este mecanismo de sinalização da transparência e da confiabilidade dos balanços não é revelador de empresas de melhor governança. Diante das lacunas jurídicas da legislação societária e da fragilidade das normas contábeis brasileiras, qualquer grande empresa, independentemente de seu tipo de conduta, pode escolher, se assim desejar, ser auditada por companhias big five. A conseqüência imediata desse tipo de equilíbrio pooling é que empresas com melhores práticas de governança deveriam promover o seu comprometimento com seus acionistas através de outros tipos de contratos que imponham regras mais rígidas. Por exigir outros métodos de divulgação de balanços e de transparência da firma, o lançamento de ADR Nível II poderia ser, por exemplo, um mecanismo alternativo à empresa.

Também se constatou que, para os períodos que englobam os anos de 1997 e 1998, as empresas com maior discrepância entre o poder de voto e propriedade participaram mais fortemente do grupo que dilui mais os acionistas minoritários. Essa evidência empírica é coerente com a discussão feita anteriormente. Nas empresas nas quais o incentivo do controlador esteve mais desalinhado com o dos demais acionistas (via desejo por aumentar o prêmio de controle da empresa), encontrou-se uma maior diluição imposta aos minoritários. Note, entretanto, que apenas para o período mais recente esta variável foi estimada insignificante, o que também é consistente com as alterações ocorridas na regulamentação da CVM a partir de 1999. Examinando-se também a tabela 1, podemos observar que a média da variável de discrepância é relativamente mais próxima entre os dois grupos para os anos de 1999 a 2000.

Conforme já discutido, em virtude dos projetos de privatizações em 1997, o governo diminuiu o benefício dos acionistas minoritários nas vendas envolvendo blocos de controle da firma. No entanto em 1999, as regras foram novamente alteradas para recompor a piora promovida anteriormente. O que podemos constatar empiricamente foi que o efeito da discrepância entre o poder de voto e propriedade 
do controlador só foi significante quando adicionamos os anos de 1997 e 1998, justamente quando a legislação em vigor era mais fraca em relação aos deveres do controlador em relação aos acionistas minoritários. Deste modo, essa evidência também corrobora a idéia de que a lei também importa, afetando a decisão da firma em proteger melhor os interesses dos seus acionistas minoritários. Este argumento serve de respaldo empírico para a discussão feita anteriormente sobre a necessidade de uma convergência legal para padrões mais rígidos de proteção.

Algumas variáveis de controle demonstraram ser, de fato, importantes para a análise. Empresas maiores e cujo lucro do período foi mais expressivo tenderam a participar mais fortemente do grupo que dilui menos seus acionistas minoritários. Isto corrobora a idéia de que seja mais fácil que grandes empresas distribuam um percentual maior dos seus lucros quando esses são relativamente fartos, ou seja, quando o que restar para a empresa também for relativamente mais significante para suas novas decisões de investimento. Para o período menos recente, a variável de alavancagem da firma pareceu afetar a sua inclusão no Grupo I, ou seja, naquele que dilui mais os seus acionistas. Este poderia ser um indício de que tal variável sinalizaria outras características das firmas ligadas a sua pior governança, conforme também existe alguma evidência na literatura. No entanto, poderia ser apenas uma decorrência do fato de empresas mais endividadas terem menor financiamento por ações e conseqüentemente menos dividendos a serem distribuídos.

\subsection{Performance das firmas em choques de retorno}

\section{Crise Asiática}

Segundo Mitton (2002) e Lemmon e Lins (2003), o período a ser analisado para crise asiática compreende os meses de julho de 1997 a agosto 1998. Na tabela 4 encontram-se os coeficientes estimados e seus respectivos p-valores para diversas regressões, que tem como base a equação (1). Em todas as estimações desta seção, os desvios padrões foram calculados pela matriz de White para correção de heterocedasticidade.

Os coeficientes estimados para as empresas que possuíam ADR foram consistentes com a premissa, discutida anteriormente, de maior contágio sofrido por esses papéis em épocas de crises internacionais. Em momentos como este, tais papéis são os primeiros a serem vendidos pelos investidores internacionais que desejam se desfazer de sua posição em países emergentes. Em vista disso, o sinal negativo do coeficiente estimado da variável ADR é consistente. Quando incluída a variável ADR níveis II e III, representativa da importância dos contratos privados 
de melhor governança, esta não teve seu coeficiente significante. No entanto, conforme a tabela 2 aponta, apenas 2 empresas possuíam este nível diferenciado de ADR na amostra em questão, o que pode ter afetado a qualidade da estimação.

Consistentemente com Johnson et alii (2000), empresas com piores características de governança obtiveram pior desempenho. Pelas regressões (i), (ii) e (iii) podemos observar que quanto mais discrepante era a estrutura de concentração de direito de voto em relação ao de propriedade, pior foi o retorno relativo da firma. Tal resultado ratifica a evidência da subseção 3.1, na qual esta variável também se mostrou significante para a conduta da firma em relação aos seus acionistas minoritários. Mais ainda, pelo fato da Crise Asiática se enquadrar no período no qual a legislação societária brasileira esteve fragilizada, corrobora-se a evidência em relação à importância da lei em momentos extremos, como o vivenciado diante de um choque tão brutal de retorno.

Em relação ao payout, ainda nessas equações, para cada $1 \%$ dos lucros distribuídos pelas empresas no exercício anterior, o seu retorno na crise teria sido maior em cerca de 1\%, observando as três primeiras regressões. As empresas que diluíram menos os seus acionistas minoritários no período anterior à crise seriam aquelas que contariam com melhor estrutura de governança, encontrando-se, assim, mais uma evidência de um impacto positivo em seu retorno relativo. Este resultado, mais uma vez, ratifica as implicações do modelo de Johnson et alii (2000) aplicado para as empresas brasileiras. Note que este resultado não parece ser robusto quando analisamos as demais regressões, no entanto, deve-se ressaltar que nestas foram adicionadas 3 variáveis explicativas não significantes e o número de observações também sofreu redução.

A variável que mede a liquidez da ação em bolsa apresentou sinal positivo e também significante nas regressões (i) e (ii). Isto comprova a idéia de que papéis mais líquidos domesticamente sofram menos com grandes movimentos de compras e vendas característicos de períodos de alta turbulência. Este resultado poderia levar a interpretação de que, ao contrário do efeito da liquidez externa, via presença de ADR, contribuir para o aumento da volatilidade dos retornos das firmas, a liquidez interna caminharia no sentido de diminuir a volatilidade dos retornos. Outro resultado encontrado foi de que ao contrário da idéia comum de que empresas com maior alavancagem têm pior retorno em épocas de crise, o sinal encontrado para o coeficiente associado a essa variável foi positivo e significante.

Todas as demais regressões, (iv), (v), (vi) e (vii), foram utilizadas como testes adicionais para a robustez das estimações diante da possibilidade das variáveis fundamentalistas afetarem o retorno esperado das firmas. Os resultados encontrados são de que esses fatores adicionais são insignificantes na regressão, sendo apenas 
o Beta do CAPM relevante para a explicação da diferença de retornos relativos. Todas as regressões indicaram que as empresas que detinham um beta maior nesse período obtiveram um pior desempenho relativo, consistentemente com a queda sofrida pelo portfolio do mercado. Em suma, quando se adicionaram as variáveis do modelo relacionadas a governança corporativa, observou-se nas regressões (i), (ii) e (iii) que estas possuem poder explicativo para outros aspectos do retorno das empresas em épocas de crise que não o do modelo padrão do CAPM.

\section{Desvalorização do Real}

O choque da desvalorização do Real em 13 de janeiro de 1999 foi responsável por uma maior perspectiva de lucros futuros para as empresas devido aos ganhos de competitividade advindos do fim do regime cambial anterior. Embora o mercado já estivesse trabalhando com a expectativa de mudanças do regime cambial, a data certa deste evento e o relativo sucesso da economia brasileira na sua recuperação foram surpreendentes diante da experiência de outros países que sofreram o mesmo trauma da desvalorização. Apesar de positivo para a média das empresas do índice BOVESPA, conforme observado pela performance do índice pós-desvalorização, o seu efeito positivo é menos evidente no nível da firma em função da exposição cambial líquida no passivo de cada empresa. A ausência de dados públicos de exposição cambial líquida das firmas (financeira e principalmente operacional) impediu um melhor controle deste aspecto, no entanto cabe ressaltar que apenas 1 empresa da amostra (de 47 firmas) apresentou retorno não positivo diante do choque.

O estudo de um choque positivo de retorno no contexto do modelo de Johnson et alii (2000) é inédito ${ }^{15}$ e possibilita testar a robustez da hipótese de que os contratos privados para boas práticas de governança seriam menos preciosos em momentos de expansão do mercado. Ao contrário da crise asiática, o modelo de Johnson et alii (2000) prevê que em choques positivos, como a da desvalorização do Real, o desalinhamento de incentivos entre o controlador da firma e os demais acionistas seja menor, sendo assim favorecidas as empresas com pior estrutura de governança corporativa.

As regressões apresentadas na tabela 5 apontam para a verificação empírica da afirmação feita acima. As variáveis de governança corporativa apontam um retorno menor para as empresas que tinham melhor postura em relação aos seus acionistas minoritários. Pela equação (v), as empresas que diluíam menos os seus acionistas minoritários, isto é, tinham um maior payout, obtiveram um retorno

\footnotetext{
${ }^{15} \mathrm{O}$ autor não encontrou este tipo de teste na literatura existente.
} 
menor de $16 \%$ para cada $1 \%$ adicional de lucro distribuído. Para todas as demais regressões estimadas, essa variável continuou negativa e significante.

Contrariamente ao período do choque negativo, a variável que indica a discrepância entre o poder de voto e propriedade teve coeficiente positivo e significante em todas as regressões. Esse sinal positivo indica que as empresas obtiveram um retorno relativo maior quando também era maior o conflito de interesses entre o controlador e os investidores. Ao encontrarmos um prêmio positivo para as empresas com maiores conflitos de interesses entre o controlador e os demais acionistas, pode-se estar constatando que antes do choque positivo, responsável por um realinhamento desses interesses, o mercado descontava significativamente a possibilidade de extração de benefícios privados destas firmas, expectativa esta que foi revertida quando do choque positivo.

O efeito ADR sobre o retorno relativo das empresas também teve sinal contrário ao encontrado na crise asiática. Por estarem mais expostas aos investidores estrangeiros, empresas que estavam listadas em alguma bolsa americana tiveram um patamar de retorno significativamente superior ao das firmas que só estavam listadas no Brasil. Em momentos de euforia dos investidores internacionais em relação a performance das firmas brasileiras, a alta liquidez das empresas com ADR' s pressionou o seu preço para cima, uma vez que o custo de transação desses papéis seria menor para este tipo de investidor. Analogamente à Crise Asiática, quando incluída a variável ADR níveis II e III, que seria representativa da importância dos contratos privados de melhor governança, esta não teve sinal significante. Assim como na Crise Asiática, apenas 2 empresas da amostra em questão possuíam algum nível diferenciado de ADR.

Nota-se, também, que as variáveis fundamentalistas demonstraram ter alguma importância para a explicação dos retornos das firmas nesse período, como confirmam os resultados das regressões (iii), (iv) e (v). Além disso, firmas maiores e menos alavancadas obtiveram um desempenho relativo pior.

\section{Crise de 11 de Setembro}

A crise de 11 de Setembro de 2001, deflagrada por uma série de atentados terroristas contra os Estados Unidos, foi, indubitavelmente, um evento inesperado e relevante para o retorno dos mercados de capitais. Adicionalmente, por se tratar de um período onde a BOVESPA já havia selecionado as empresas do Nível 1 de Governança Corporativa, podemos testar o efeito diferenciado deste contrato privado para melhores práticas de transparência e governança das firmas.

Os principais resultados das estimações encontram-se na tabela 6, cuja princi- 
pal novidade em relação as anteriores é justamente a presença da variável Nível 1 de Governança Corporativa que indica o valor de 1 caso a empresa faça parte desse grupo diferenciado da BOVESPA e assume o valor 0 em caso contrário. Em todas as regressões estimadas, o efeito da variável Beta do CAPM foi insignificante, destacando-se, no entanto, a importância da variável fundamentalista Índice Valor Patrimonial/Preço.

Assim como na Crise Asiática, as empresas que possuíam ADR, por estarem mais expostas ao investidor externo, também apresentaram um piso de retorno relativo inferior neste momento de crise. No entanto, podemos encontrar um sinal significante para as empresas que possuíam ADR Nível II ou III, ou seja, que realmente estavam diante de um contrato para melhores práticas de governança corporativa. Conforme a tabela 2 informa, havia 11 empresas com este nível diferenciado de ADR para essa crise, o que permitiu uma estimação mais eficiente. A tabela 6 demonstra que a presença de uma empresa brasileira listada em alguma bolsa americana com padrões mais rígidos de governança corporativa rendeu um desempenho superior de cerca de $7 \%$ no período.

Diante desta perspectiva e dos resultados dos três choques estudados, não seria correto afirmar que o efeito da listagem de ADR' s Nível I seria o de aumentar a transparência da firma. Portanto, também não poderíamos transladar o resultado de Mitton (2002) para o Brasil, uma vez que das 40 observações de empresas com ADR enquadradas como sendo de melhor transparência no estudo de Mitton (2002) apenas 5 possuíam ADR que não de Nível I. Em vista disto e dos dois efeitos (contrários) encontrados na listagem de ADR, um de governança corporativa e outro de exposição aos investidores externos, o resultado obtido por este artigo proporciona um melhor entendimento dos impactos que a presença de ADR' s pode ter para firmas brasileiras em momentos de choques de retorno.

A possibilidade de se utilizar a variável Nível 1 de Governança Corporativa apenas confirmou o efeito encontrado sobre a importância deste tipo de contrato em momentos de crise. Empresas detentoras desse tipo de contrato para melhores práticas de governança tiveram um retorno superior, que foi quantificado como sendo de aproximadamente $6 \%$. Isso serviria como um bom indício para a BOVESPA confirmar a efetividade de suas regras diferenciadas. Também seria indicativo de que o fato deste contrato não ter garantias da legislação americana, como os de ADR's, não teria sido prejudicial para a sua efetividade prática.

A variável de discrepância entre poder de voto do controlador em relação ao seu poder de propriedade da firma, apesar de sempre com sinal consistente com o modelo, mostrou-se insignificante. Assim como o resultado da subseção 3.1 para o período mais recente apontou, isto mais uma vez é coerente com a mudança 
ocorrida na legislação societária brasileira a partir da Instrução 299 da CVM que, já em vigor nesse período, reduziu os benefícios dos controladores nos processo de alienação do controle, além de promover melhorias no direito de recesso dos acionistas minoritários. Diante de uma legislação menos fragilizada, a relevância dessa variável foi diminuída.

Por fim, para apenas esse choque, o payout não apresentou indícios significativos de seu impacto sobre a performance diferenciada das firmas. As outras variáveis de controle, tais como Tamanho da Firma, Alavancagem e Liquidez também não se mostraram relevantes na determinação dos retornos para a amostra em questão.

\section{Conclusão}

Conforme foi discutido, este artigo caminhou paralelamente à literatura recente de governança corporativa, na qual diversos artigos trataram esta temática com um enfoque global, ou seja, compararam diversas estruturas legais de proteção aos acionistas minoritários ao redor do mundo e suas várias implicações. O objetivo deste artigo foi, portanto, ressaltar a importância de diferentes práticas de governança da firma dentro de um mesmo país, sendo que estas podem advir tanto da assinatura de contratos privados ou das próprias características das firmas. A abordagem empírica desenvolvida para as empresas brasileiras de capital aberto evidenciou tal afirmação, tanto para suas conseqüências sobre a conduta das firmas em relação à diluição dos seus acionistas minoritários como para a sua performance em momentos de crises. Como um resultado empírico robusto, pode-se afirmar que melhores práticas de governança corporativa tendem a diminuir a volatilidade do retorno das firmas.

As idéias expostas por Coffee (1999) para uma convergência funcional com regras de maior proteção foram comprovadas para contratos que, na prática, representavam ganho em termos de governança corporativa e transparência da firma. Empresas que possuíam ADR Nível II ou faziam parte do Nível 1 de Governança Corporativa da BOVESPA tiveram maiores chances de fazer parte do grupo de empresas que diluem menos os seus acionistas minoritários e além disso tiveram performance relativamente superior na crise de 11 de setembro, quando, diante de um choque negativo de retorno, o desvio de recursos das firmas se tornou mais atraente.

No entanto, a simples presença de firmas brasileiras no mercado americano através de ADR Nível I, que não conta com regras diferenciadas de transparência e proteção, e a presença de auditorias de boa reputação não pareceram afetar o 
comportamento da firma em relação aos seus investidores externos. Diante das lacunas jurídicas da legislação societária e da fragilidade das normas contábeis brasileiras, não seria errôneo afirmar que o fato da firma ser auditada por uma companhia de alta reputação independe de seu tipo de conduta, uma vez que a própria lei é falha em relação ao rigor dos balanços e a sua verificação.

A necessidade de uma Lei das S.A. mais rígida e que promova maior proteção aos interesses dos acionistas minoritários também pode ser comprovada no estudo aqui apresentado. Assim como a defesa da importância de uma convergência legal explicita, em momentos onde a legislação societária brasileira foi enfraquecida, os problemas de extração de benefícios privados da firma se tornaram mais significativos. No entanto, a conclusão principal deste trabalho é que, caso algumas firmas ou o próprio mercado de capitais não vejam os avanços da lei como suficientes para as suas necessidades em termos de governança corporativa, então a assinatura de contratos privados pode ser eficaz para este processo.

\section{Referências}

Coffee, J. (1999). The future as history: The prospects for global convergence in corporate governance and its implications. Northwestern University Law Review, 93:631-707.

Costa Jr, N. e Neves, M. (2000). Variáveis fundamentalistas e os retornos das ações. Revista Brasileira de Economia, 54:123-137.

Fama, E. \& French, K. (1996). Multifactor explanations of asset pricing anomalies. Journal of Finance, 51:55-84.

Grossman, S. \& Hart, O. (1986). The costs and benefits of ownership: A theory of vertical and lateral integration. Journal of Political Economy, 94:691-719.

Jensen, M. \& Meckling, W. (1976). Theory of the firm: Managerial behavior, agency costs and ownership structure. Journal of Financial Economics, 3:30560.

Johnson, S., Boone, P., Breach, A., \& Friedman, E. (2000). Corporate governance in the asian financial crisis. Journal of Financial Economics, 58:141-186.

Johnson, S. \& Shleifer, A. (2001). Privatization and corporate governance. $12^{\mathrm{O}}$ Annual East Asian Seminar on Economics, mimeo. 
La Porta, R., Lopez-de Silanes, F., A., S., \& Vishney, R. (2000a). Agency problems and dividend policies around the world. Journal of Finance, 55:1-34.

La Porta, R., Lopez-de Silanes, F., A., S., \& Vishney, R. (2000b). Investor protection and corporate governance. Journal of Financial Economics, 58(1-2):3-27.

Lemmon, M. \& Lins, K. (2003). Ownership structure, corporate governance, and firm value: Evidence from the East Asian financial crisis. The Journal of Finance, 58:1445-1468.

Lins, K., Strickland, D., \& Zenner, M. (2004). Do non-US firms issue stock on U.S. equity markets to relax capital constraints? Journal of Financial Quantitative Analysis.

Miller, D. (1999). The market reaction to international cross-listings: Evidence from depositary receipts. Journal of Financial Economics, 5:103-123.

Mitton, T. (2002). A cross-firm analysis of the impact of corporate governance on the East Asian financial crisis. Journal of Financial Economics, 64(2).

Rajan, R. \& Zingales, L. (1998). Which capitalism? Lessons from the East Asian crisis. Journal of Applied Corporate Finance, 11:40-48.

Reese, W. \& Weisbach, M. (2002). Protection of minority shareholder interests, cross-listings in the United States, and subsequent equity offerings. Journal of Financial Economics, 66:65-104.

Valadares, S. \& Leal, R. P. C. (2000). Ownership and control structure of Brazilian companies. Abante, 3(1):29-56. 


\section{Anexo}

Tabela A.1

Número de firmas, desvio padrão, média e p-valor (para médias iguais entre os grupos)

O Grupo I, formado por empresas que diluem mais os seus acionistas, é composto, a cada período, pelas as companhias que possuíam um payout inferior ao médio das empresas. A variável ADR é uma dummie para as empresas listadas no mercado americano no período enquanto ADR nível II é uma dummie apenas para aquelas que são de nível II. Nível 1 de Governança Corporativa é uma dummie para empresas que satisfazem critérios mais rígidos de governança estabelecidos pela BOVESPA. Big five é uma variável que indica se a firma é auditada por uma companhia do grupo das big five: Arthur Andersen, Ernst \& Young, Price WaterHouse Coopers, Deloitte Touche Tohmatsu e KPMG. A variável discrepância indica a razão entre a porcentagem das ações da firma com direito a voto possuída pelo maior acionista em relação à porcentagem total de ações da firma que este detêm no período. A alavancagem da firma é a razão do valor escritural da dívida da firma sobre o seu patrimônio líquido. O tamanho da firma é dado pelo logaritmo do ativo total da firma durante o período em questão. A variável de liquidez é uma medida de liquidez em bolsa da Economática. Por fim, a lucratividade da empresa foi calculada como a razão do lucro sobre o ativo total da firma. Os P-Valores são calculados para a hipótese nula de que a média das variáveis é idêntica entre os grupos

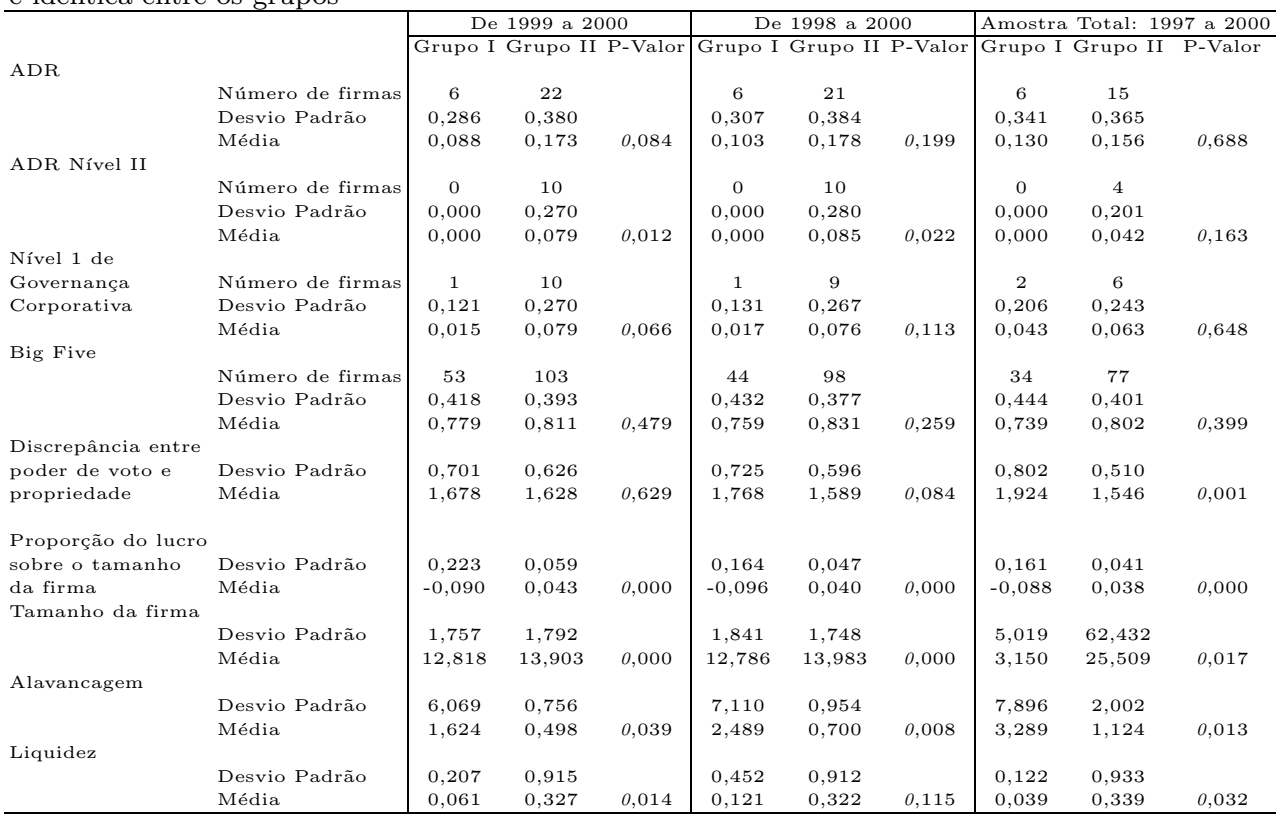


Tabela A.2

Estatísticas descritivas e correlação das variáveis nos períodos de choque de retorno

Abaixo, encontra-se um sumário estatístico das variáveis utilizadas nas regressões para a crise Asiática, Brasileira e de 11 de Setembro. A amostra de empresas, em cada crise, é composta por aquelas que faziam parte do índice do International Finance Corporation para as firmas mais relevantes de um país e, além disso, estavam entre as 70 mais líquidas da BOVESPA. O retorno das empresas é calculado para o período indicado. O Beta do CAPM de cada empresa foi estimado com base nos 60 meses anteriores ao início de cada crise. A variável discrepância indica a razão entre a porcentagem das ações da firma com direito a voto possuída pelo maior acionista em relação à porcentagem total de ações da firma que este detêm. $\mathrm{O}$ payout foi calculado como a proporção dos lucros do exercício imediatamente anterior a cada crise que foi proposta para ser distribuída entre os acionistas da firma. A variável de liquidez é uma medida de liquidez das ações em bolsa computada pela Economática para o mês anterior a cada crise. A alavancagem da firma é a razão do valor escritural da dívida da firma sobre o seu patrimônio líquido, sendo que esta razão é medida no exercício anterior a cada crise. Empresas com ADR são aquelas que possuíam ações listadas em alguma bolsa americana no período, enquanto ADR nível II representa apenas as empresas que possuíam esse nível. Por fim, Nível 1 de Governança Corporativa é uma definição da BOVESPA para empresas que satisfaçam critérios mais rígidos de governança

\begin{tabular}{|c|c|c|c|}
\hline \multicolumn{4}{|c|}{ Painel A: Estatísticas Descritivas } \\
\hline \multirow{3}{*}{ Período } & Crise Asiática & Desvalorização do Real & 11 de Setembro \\
\hline & 01 de Julho de 1997 a & 13 de Janeiro de 1999 a & 11 Setembro de 2001 a \\
\hline & 30 de Agosto de 1998 & 18 de Janeiro de 2000 & 04 de Outubro de 2001 \\
\hline \multirow{2}{*}{\multicolumn{4}{|c|}{$\begin{array}{l}\text { Empresas que fizeram } \\
\text { parte da amostra }\end{array}$}} \\
\hline & & & \\
\hline \multicolumn{4}{|l|}{ Retorno das empresas } \\
\hline Média & $-0,259$ & 2,211 & $-0,142$ \\
\hline Mediana & $-0,353$ & 1,774 & $-0,114$ \\
\hline Máximo & 0,311 & 10,111 & 0,003 \\
\hline Mínimo & $-0,631$ & $-0,186$ & $-0,424$ \\
\hline \multicolumn{4}{|l|}{ Beta do Capm } \\
\hline Média & 0,883 & 0,820 & 0,730 \\
\hline Mediana & 0,865 & 0,810 & 0,710 \\
\hline Máximo & 1,290 & 1,260 & 1,130 \\
\hline Mínimo & 0,680 & 0,510 & 0,260 \\
\hline \multicolumn{4}{|c|}{$\begin{array}{l}\text { Discrepância entre poder } \\
\text { de voto e propriedade }\end{array}$} \\
\hline Média & 1,842 & 1,778 & 1,740 \\
\hline Mediana & 1,877 & 1,679 & 1,588 \\
\hline Máximo & 2,998 & 3,000 & 2,998 \\
\hline Mínimo & 0,926 & 0,853 & 0,746 \\
\hline \multicolumn{4}{|l|}{ Payout } \\
\hline Média & 0,499 & 0,943 & 1,865 \\
\hline Mediana & 0,334 & 0,350 & 0,341 \\
\hline Máximo & 2,878 & 23,494 & 52,106 \\
\hline Mínimo & 0,000 & $-0,426$ & $-1,971$ \\
\hline \multicolumn{4}{|l|}{ Liquidez } \\
\hline Média & 0,768 & 0,625 & 0,765 \\
\hline Mediana & 0,252 & 0,100 & 0,286 \\
\hline Máximo & 5,134 & 6,753 & 7,339 \\
\hline Mínimo & 0,040 & 0,003 & 0,005 \\
\hline \multicolumn{4}{|l|}{ Alavancagem } \\
\hline Média & 0,149 & 0,284 & 0,272 \\
\hline Mediana & 0,061 & 0,110 & 0,096 \\
\hline Máximo & 0,978 & 1,854 & 1,691 \\
\hline Mínimo & 0,004 & 0,030 & 0,008 \\
\hline
\end{tabular}




\begin{tabular}{|c|c|c|c|}
\hline Período & $\begin{array}{l}01 \text { de Julho de } 1997 \text { a } \\
30 \text { de Agosto de } 1998\end{array}$ & $\begin{array}{c}13 \text { de Janeiro de } 1999 \text { a } \\
18 \text { de Janeiro de } 2000\end{array}$ & $\begin{array}{l}11 \text { Setembro de } 2001 \text { a } \\
04 \text { de Outubro de } 2001\end{array}$ \\
\hline \multicolumn{4}{|c|}{ ( } \\
\hline Média & 10,703 & 13,668 & 15,187 \\
\hline Mediana & 2,444 & 2,554 & 3,494 \\
\hline Máximo & 77,572 & 130,000 & 147,000 \\
\hline Mínimo & 0,334 & 0,156 & 0,345 \\
\hline \multicolumn{4}{|l|}{ Índice Preço/Lucro } \\
\hline Média & 0,042 & 0,005 & 0,005 \\
\hline Mediana & 0,013 & 0,005 & 0,006 \\
\hline Máximo & 0,629 & 0,061 & 0,033 \\
\hline Mínimo & $-0,028$ & $-0,017$ & $-0,027$ \\
\hline \multicolumn{4}{|l|}{ Valor de Mercado } \\
\hline Média & 0,051 & 0,019 & 0,050 \\
\hline Mediana & 0,010 & 0,004 & 0,008 \\
\hline Máximo & 0,356 & 0,145 & 0,596 \\
\hline Mínimo & 0,001 & 0,000 & 0,001 \\
\hline \multicolumn{4}{|l|}{ Índice Valor Patrimonial/Preço } \\
\hline Média & 1,385 & 2,841 & 0,765 \\
\hline Mediana & 1,000 & 2,165 & 0,286 \\
\hline Máximo & 4,132 & 11,905 & 7,339 \\
\hline Mínimo & 0,387 & 0,377 & 0,005 \\
\hline Empresas com ADR & 9 & 11 & 20 \\
\hline $\begin{array}{l}\text { Empresas com ADR } \\
\text { Níveis II e III }\end{array}$ & 2 & 2 & 11 \\
\hline $\begin{array}{l}\text { Empresas que fazem parte do } \\
\text { nível } 1 \text { de governança } \\
\text { corporativa da Bovespa }\end{array}$ & - & - & 6 \\
\hline
\end{tabular}


Tabela A.3

Probit para a diluição dos acionistas minoritários da firma

Os Painéis A, B e C reportam os coeficientes e p-valores (embaixo e em itálico) da estimação de um modelo Probit para a determinação da probabilidade de uma firma fazer parte do Grupo II, ou seja, do grupo de empresas que diluem menos os seus acionistas minoritários. Os desvios padrões foram calculados pela matriz de robustez de Huber e White. O Grupo I, formado por empresas que diluem mais os seus acionistas, é composto, a cada período, pelas as companhias que possuíam um payout inferior ao médio das empresas. A variável ADR é uma dummie para as empresas listadas no mercado americano no período enquanto ADR nível II é uma dummie apenas para aquelas que são de nível II. Nível 1 de Governança Corporativa é uma dummie para empresas que satisfazem critérios mais rígidos de governança estabelecidos pela BOVESPA. Big five é uma variável que indica se a firma é auditada por uma companhia do grupo das big five: Arthur Andersen, Ernst \& Young, Price WaterHouse Coopers, Deloitte Touche Tohmatsu e KPMG. A variável discrepância indica a razão entre a porcentagem das ações da firma com direito a voto possuída pelo maior acionista em relação à porcentagem total de ações da firma que este detêm no período. A alavancagem da firma é a razão do valor escritural da dívida da firma sobre o seu patrimônio líquido. O tamanho da firma é dado pelo logaritmo do ativo total da firma durante o período em questão. A variável de liquidez e as dummies setoriais foram calculadas baseadas nas informações da Economática. Por fim, a lucratividade da empresa foi calculada como a razão do lucro sobre o ativo total da firma

Painel A: coeficentes estimados do probit

Amostra total:

\begin{tabular}{lccc} 
& De 1999 a 2000 & De 1998 a 2000 & De 1997 a 2000 \\
\hline ADR & $-0,240$ & $-0,751$ & $-0,458$ \\
ADR Nível II & 0,628 & 0,127 & 0,169 \\
& 8,080 & 7,502 & 0,891 \\
Nível 1 de Governança Corporativa & 0,000 & 0,000 & 0,054 \\
& 1,476 & 1,978 & $-0,120$ \\
Big Five & 0,002 & 0,000 & 0,826 \\
& $-0,780$ & 0,037 & $-0,426$ \\
Discrepância entre poder de voto & 0,038 & 0,932 & 0,192 \\
e propriedade & $-0,194$ & $-0,710$ & $-0,396$ \\
& 0,328 & 0,012 & 0,032 \\
Proporção do lucro sobre o & & & 6,580 \\
tamanho da firma & 9,701 & 22,174 & 0,000 \\
& 0,000 & 0,000 & 0,008 \\
Tamanho da firma & & & 0,003 \\
& 0,286 & 0,280 & $-0,083$ \\
Alavancagem & 0,008 & 0,039 & 0,000 \\
& $-0,109$ & $-0,273$ & 0,235 \\
Liquidez & 0,242 & 0,084 & 0,124 \\
Dummies Setoriais & 0,291 & $-0,293$ & Incluídas \\
McFadden R2 & 0,280 & 0,335 & 0,501 \\
Número Total de Observações & Incluídas & Incluídas & 142 \\
Grupo I & 0,413 & 0,607 & 46 \\
Grupo II & 195 & 176 & 96 \\
\hline
\end{tabular}




\begin{tabular}{lccc}
\hline Painel B: coeficentes estimados do probit - omitindo a variável ADR \\
& Amostra total: & \\
& De 1999 a 2000 & De 1998 a 2000 & De 1997 a 2000 \\
\hline ADR Nível II & 7,598 & 7,272 & 0,600 \\
& 0,000 & 0,000 & 0,134 \\
Nível 1 de Governança Corporativa & 1,470 & 2,012 & $-0,046$ \\
& 0,002 & 0,000 & 0,932 \\
Big Five & $-0,769$ & $-0,021$ & $-0,492$ \\
& 0,040 & 0,000 & 0,130 \\
Discrepância entre poder de voto & $-0,222$ & $-0,739$ & $-0,428$ \\
e propriedade & 0,286 & 0,000 & 0,021 \\
Proporção do lucro sobre o & 9,816 & 22,013 & 6,597 \\
tamanho da firma & 0,000 & 0,000 & 0,000 \\
Tamanho da firma & 0,278 & 0,282 & 0,008 \\
& 0,008 & 0,000 & 0,006 \\
Alavancagem & $-0,110$ & $-0,277$ & $-0,080$ \\
& 0,246 & 0,000 & 0,000 \\
Liquidez & 0,274 & $-0,425$ & 0,229 \\
& 0,298 & 0,000 & 0,115 \\
Dummies Setoriais & Incluídas & Incluídas & Incluídas \\
McFadden R2 & 0,412 & 0,600 & 0,494 \\
Número Total de Observações & 195 & 176 & 142 \\
Grupo I & 68 & 58 & 46 \\
Grupo II & 127 & 118 & 96 \\
\hline
\end{tabular}


Tabela A.4

Retorno das empresas na crise asiática

A tabela a seguir reporta os coeficientes e os p-valores (embaixo e em itálico) das variáveis que, segundo o modelo descrito no artigo, influenciam o retorno da firma em momentos de crises. Os desvios padrões foram calculados pela matriz de White para correção de heterocedasticidade. O Beta do CAPM de cada empresa foi estimado com base nos 60 meses anteriores ao mês de início da crise. A variável discrepância indica a razão entre a porcentagem das ações da firma com direito a voto possuída pelo maior acionista em relação à porcentagem total de ações da firma que este detêm. O payout foi calculado como a proporção dos lucros do exercício de 1996 que foi proposta para ser distribuída entre os acionistas da firma em 1997. A variável de liquidez é uma medida de liquidez das ações em bolsa computada pela Economática para o mês de Junho de 1997. A alavancagem da firma é a razão do valor escritural da dívida da firma sobre o seu patrimônio líquido no exercício de 1996. O tamanho da firma é dado pelo logaritmo do ativo total de Junho de 1997. As variáveis fundamentalistas foram obtidas para o mês de Junho de 1997 utilizando a Economática. Empresas com ADR são aquelas que possuíam ações listadas em alguma bolsa americana nesse período, enquanto ADR Níveis II e III representam as empresas listadas com regras específicas de governança corporativa

\begin{tabular}{lccccccc}
\hline & (i) & (ii) & (iii) & (iv) & (v) & (vi) & (vii) \\
\hline Constante & 0,391 & 0,403 & 0,365 & $-0,169$ & 0,376 & 0,375 & 0,368 \\
& 0,083 & 0,087 & 0,101 & 0,284 & 0,286 & 0,284 & 0,311 \\
ADR & $-0,173$ & $-0,164$ & $-0,192$ & $-0,185$ & $-0,236$ & $-0,221$ & $-0,230$ \\
& 0,012 & 0,031 & 0,021 & 0,044 & 0,018 & 0,014 & 0,023 \\
ADR Níveis II e III & & $-0,064$ & & & 0,044 & & 0,041 \\
& & 0,408 & & & 0,647 & & 0,682 \\
Discrepância entre poder & $-0,117$ & $-0,117$ & $-0,111$ & $-0,111$ & $-0,136$ & $-0,134$ & $-0,136$ \\
de voto e propriedade & 0,015 & 0,018 & 0,025 & 0,120 & 0,104 & 0,100 & 0,115 \\
Payout & 0,014 & 0,014 & 0,013 & 0,022 & $-0,042$ & $-0,040$ & $-0,043$ \\
& 0,036 & 0,037 & 0,069 & 0,774 & 0,613 & 0,628 & 0,622 \\
Beta do CAPM & $-0,566$ & $-0,580$ & $-0,540$ & & $-0,540$ & $-0,549$ & $-0,537$ \\
& 0,008 & 0,011 & 0,009 & & 0,074 & 0,056 & 0,083 \\
Alavancagem & 0,169 & 0,170 & 0,148 & 0,463 & 0,346 & 0,379 & 0,377 \\
& 0,022 & 0,022 & 0,020 & 0,004 & 0,044 & 0,139 & 0,150 \\
Tamanho & & & 0,002 & & & $-0,001$ & $-0,001$ \\
& & & 0,472 & & & 0,859 & 0,882 \\
Liquidez & 0,087 & 0,087 & 0,065 & 0,064 & 0,076 & 0,072 & 0,072 \\
& 0,006 & 0,007 & 0,188 & 0,335 & 0,287 & 0,366 & 0,379 \\
Índice Preço/Lucro & & & & $-0,239$ & $-0,152$ & $-0,176$ & $-0,164$ \\
& & & & 0,327 & 0,539 & 0,448 & 0,526 \\
Valor de Mercado & & & & $-0,021$ & 0,023 & 0,045 & 0,042 \\
& & & & 0,803 & 0,775 & 0,790 & 0,807 \\
Índice Valor Patrimonial/Preço & & & & 0,033 & 0,038 & 0,039 & 0,040 \\
& & & & 0,538 & 0,441 & 0,462 & 0,470 \\
R2 & 0,419 & 0,421 & 0,428 & 0,497 & 0,626 & 0,625 & 0,626 \\
R2 Ajustado & 0,317 & 0,298 & 0,306 & 0,336 & 0,429 & 0,428 & 0,397 \\
Observações & & & & & & & \\
incluídas: & 41 & 41 & 41 & 34 & 30 & 30 & 30 \\
\hline & & & & & & & \\
& & & & & & &
\end{tabular}


Tabela A.5

Retorno das empresas na desvalorização do Real

\begin{abstract}
A tabela a seguir reporta os coeficientes e os p-valores (embaixo e em itálico) das variáveis que, segundo o modelo descrito no artigo, influenciam o retorno da firma em momentos de crises. Os desvios padrões foram calculados pela matriz de White para correção de heterocedasticidade. O Beta do CAPM de cada empresa foi estimado com base nos 60 meses anteriores ao mês de início da crise. A variável discrepância indica a razão entre a porcentagem das ações da firma com direito a voto possuída pelo maior acionista em relação à porcentagem total de ações da firma que este detêm. O payout foi calculado como a proporção dos lucros do exercício de 1998 que foi proposta para ser distribuída entre os acionistas da firma em 1999. A variável de liquidez é uma medida de liquidez das ações em bolsa computada pela Economática para o mês de Dezembro de 1998. A alavancagem da firma é a razão do valor escritural da dívida da firma sobre o seu patrimônio líquido no exercício de 1998. O tamanho da firma é dado pelo logaritmo do ativo total de Dezembro de 1998. As variáveis fundamentalistas foram obtidas para o mês de Dezembro de 1998 utilizando a Economática. Empresas com ADR são aquelas que possuíam ações listadas em alguma bolsa americana nesse período, enquanto ADR Níveis II e III representam as empresas listadas com regras específicas de governança corporativa
\end{abstract}

\begin{tabular}{|c|c|c|c|c|c|}
\hline & (i) & (ii) & (iii) & (iv) & $(\mathrm{v})$ \\
\hline \multirow[t]{2}{*}{ Constante } & $-1,179$ & $-1,755$ & $-1,120$ & $-3,409$ & $-3,478$ \\
\hline & 0,307 & 0,174 & 0,059 & 0,007 & 0,027 \\
\hline \multirow[t]{2}{*}{ ADR } & 1,883 & 2,058 & 1,393 & 1,831 & 1,838 \\
\hline & 0,026 & 0,032 & 0,079 & 0,016 & 0,018 \\
\hline \multirow[t]{2}{*}{ ADR Níveis II e III } & & $-1,425$ & 0,078 & $-0,908$ & $-0,888$ \\
\hline & & 0,215 & 0,920 & 0,327 & 0,343 \\
\hline Discrepância entre poder & 0,827 & 0,829 & 0,823 & 0,642 & 0,646 \\
\hline de voto e propriedade & 0,010 & 0,009 & 0,004 & 0,023 & 0,028 \\
\hline \multirow[t]{2}{*}{ Payout } & $-0,090$ & $-0,127$ & $-0,102$ & $-0,158$ & $-0,160$ \\
\hline & 0,008 & 0,001 & 0,000 & 0,000 & 0,001 \\
\hline \multirow[t]{2}{*}{ Beta do CAPM } & 1,988 & 2,784 & & 2,874 & 2,933 \\
\hline & 0,190 & 0,094 & & 0,063 & 0,096 \\
\hline \multirow[t]{2}{*}{ Alavancagem } & & & 0,773 & 2,640 & 2,653 \\
\hline & & & 0,000 & 0,005 & 0,007 \\
\hline \multirow[t]{2}{*}{ Tamanho } & & & $-0,027$ & $-0,061$ & $-0,061$ \\
\hline & & & 0,001 & 0,001 & 0,002 \\
\hline \multirow[t]{2}{*}{ Liquidez } & $-0,145$ & $-0,209$ & $-0,685$ & $-0,751$ & $-0,755$ \\
\hline & 0,467 & 0,362 & 0,028 & 0,044 & 0,049 \\
\hline \multirow[t]{2}{*}{ Índice Preço/Lucro } & & & & & 1,721 \\
\hline & & & & & 0,901 \\
\hline \multirow[t]{2}{*}{ Valor de Mercado } & & & 4,690 & 5,620 & 5,630 \\
\hline & & & 0,002 & 0,001 & 0,002 \\
\hline \multirow[t]{2}{*}{ Índice Valor Patrimonial/Preço } & & & 0,468 & 0,482 & 0,483 \\
\hline & & & 0,001 & 0,001 & 0,001 \\
\hline $\mathrm{R} 2$ & 0,401 & 0,416 & 0,682 & 0,737 & 0,737 \\
\hline R2 Ajustado & 0,328 & 0,328 & 0,602 & 0,655 & 0,643 \\
\hline \multicolumn{6}{|l|}{ Observações } \\
\hline incluídas: & 47 & 47 & 46 & 43 & 43 \\
\hline
\end{tabular}


Tabela A.6

Retorno das empresas na crise de 11 de Setembro

A tabela a seguir reporta os coeficientes e os p-valores (embaixo e em itálico) das variáveis que, segundo o modelo descrito no artigo, influenciam o retorno da firma em momentos de crises. Os desvios padrões foram calculados pela matriz de White para correção de heterocedasticidade. O Beta do CAPM de cada empresa foi estimado com base nos 60 meses anteriores ao mês de início da crise. A variável discrepância indica a razão entre a porcentagem das ações da firma com direito a voto possuída pelo maior acionista em relação à porcentagem total de ações da firma que este detêm. O payout foi calculado como a proporção dos lucros do exercício de 2000 que foi proposta para ser distribuída entre os acionistas da firma em 2001. A variável de liquidez é uma medida de liquidez das ações em bolsa computada pela Economática para o mês de Agosto de 2001. A alavancagem da firma é a razão do valor escritural da dívida da firma sobre o seu patrimônio líquido no exercício de 2000. O tamanho da firma é dado pelo logaritmo do ativo total de Agosto de 2001. As variáveis fundamentalistas foram obtidas para o mês de Agosto de 2001 utilizando a Economática. Empresas com ADR são aquelas que possuíam ações listadas em alguma bolsa americana nesse período, enquanto ADR Níveis II e III representam as empresas listadas com regras específicas de governança corporativa. Por fim, Nível 1 de Governança Corporativa é uma definição da BOVESPA para empresas que satisfaçam critérios mais rígidos de governança

\begin{tabular}{lcrrrrr}
\hline & (i) & (ii) & \multicolumn{1}{c}{ (iii) } & (iv) & (v) & (vi) \\
\hline Constante & $-0,099$ & $-0,056$ & $-0,075$ & 0,025 & $-0,001$ & 0,005 \\
& 0,007 & 0,198 & 0,118 & 0,706 & 0,988 & 0,932 \\
ADR & $-0,072$ & $-0,068$ & $-0,080$ & $-0,012$ & $-0,078$ & $-0,077$ \\
& 0,012 & 0,039 & 0,013 & 0,759 & 0,045 & 0,064 \\
ADR Níveis II e III & 0,073 & 0,079 & 0,073 & & 0,099 & 0,078 \\
& 0,022 & 0,025 & 0,028 & & 0,005 & 0,074 \\
Nível 1 de Governança Corporativa & 0,050 & 0,060 & 0,054 & 0,095 & & 0,062 \\
& 0,009 & 0,011 & 0,015 & 0,006 & & 0,055 \\
Discrepância entre poder & & $-0,002$ & $-0,012$ & $-0,004$ & $-0,015$ & $-0,019$ \\
de voto e propriedade & & 0,942 & 0,538 & 0,838 & 0,471 & 0,354 \\
Payout & & $-0,001$ & $-0,001$ & 0,000 & 0,000 & 0,000 \\
& & 0,352 & 0,335 & 0,943 & 0,466 & 0,706 \\
Beta do CAPM & 0,070 & & 0,077 & $-0,118$ & 0,005 & $-0,019$ \\
& 0,156 & & 0,136 & 0,304 & 0,937 & 0,787 \\
Alavancagem & & & & $-0,112$ & $-0,033$ & $-0,032$ \\
& & & & 0,082 & 0,516 & 0,502 \\
Tamanho & $-0,001$ & $-0,001$ & $-0,001$ & 0,000 & $-0,001$ & $-0,001$ \\
& 0,001 & 0,004 & 0,001 & 0,887 & 0,395 & 0,172 \\
Liquidez & & & & & & 0,015 \\
& & & & & & 0,574 \\
Índice Preço/Lucro & & & & 0,201 & $-2,013$ & $-1,641$ \\
Valor de Mercado & & & & 0,903 & 0,183 & 0,255 \\
Índice Valor Patrimonial/Preço & $-0,041$ & $-0,039$ & $-0,041$ & $-0,038$ & $-0,045$ & $-0,039$ \\
R2 & 0,000 & 0,000 & 0,000 & 0,002 & 0,000 & 0,001 \\
R2 Ajustado & 0,640 & 0,575 & 0,660 & 0,587 & 0,663 & 0,699 \\
Observações & 0,577 & 0,485 & 0,569 & 0,421 & 0,523 & 0,555 \\
incluídas: & & & & & & \\
\hline
\end{tabular}

